\title{
Tuning the Adsorption Properties of Isoreticular Pyrazolate-Based Metal-Organic Frameworks through Ligand Modification
}

\author{
Valentina Colombo, ${ }^{*}{ }^{\dagger}$ Carmen Montoro, ${ }^{\ddagger}$ Angelo Maspero, ${ }^{\dagger}$ Giovanni Palmisano, ${ }^{\dagger}$ \\ Norberto Masciocchi, ${ }^{\dagger}$ Simona Galli, ${ }^{\dagger}$ Elisa Barea, ${ }^{\ddagger}$ and Jorge A. R. Navarro*, \\ ${ }^{\dagger}$ Dipartimento di Scienza e Alta Tecnologia, Università dell’Insubria, via Valleggio 11, I-22100 Como, Italy \\ ${ }^{\ddagger}$ Departamento de Química Inorgánica, Universidad de Granada, Av. Fuentenueva S/N, 18071 Granada, Spain
}

\section{Supporting Information}

ABSTRACT: Two isoreticular series of pyrazolate-based 3D open metal-organic frameworks, MBDP_X, adopting the NiBDP and ZnBDP structure types $\left[\mathrm{H}_{2} \mathrm{BD} \overline{\mathrm{DP}}=1,4\right.$-bis $(1 \mathrm{H}$ pyrazol-4-yl)benzene], were synthesized with the new tagged organic linkers $\mathbf{H}_{2} \mathbf{B D P} \mathbf{X}\left(\mathrm{X}=-\mathrm{NO}_{2},-\mathrm{NH}_{2},-\mathrm{OH}\right)$. All of the MBDP_X materials have been characterized through a combination of techniques. IR spectroscopy proved the effective presence of tags, while X-ray powder diffraction (XRPD) witnessed their isoreticular nature. Simultaneous TG/ DSC analyses (STA) demonstrated their remarkable thermal stability, while variable-temperature XRPD experiments highlighted their high degree of flexibility related to guest-induced fit processes of the solvent molecules included in the channels. A structural isomer of the parent NiBDP was obtained with a sulfonate tagged ligand, $\mathbf{H}_{2} \mathbf{B D P} \mathbf{S O}_{3} \mathbf{H}$. Structure solution from powder diffraction data collected at three different temperatures (room temperature, 90 , and $25 \overline{0}^{\circ} \mathrm{C}$ ) allowed the determination of its structure and the comprehension of its solvent-related flexible behavior. Finally, the potential application of the tagged MOFs in selective adsorption processes for gas separation and purification purposes was investigated by conventional single component adsorption isotherms, as well as by advanced experiments of pulse gas chromatography and breakthrough curve measurements. Noteworthy, the results show that functionalization does not improve the adsorption selectivity (partition coefficients) for the resolution of gas mixtures characterized by similar high quadrupole moments (e.g., $\mathrm{CO}_{2} / \mathrm{C}_{2} \mathrm{H}_{2}$ ); however, the resolution of gas mixtures containing molecules with highly differentiated polarities (i.e., $\mathrm{N}_{2} / \mathrm{CO}_{2}$ or $\mathrm{CH}_{4} / \mathrm{CO}_{2}$ ) is highly improved.

\section{INTRODUCTION}

Metal-organic frameworks (MOFs) are a new fascinating class of materials in which inorganic subunits and organic ligands are reciprocally linked by strong coordination bonds generating robust and often porous species featuring extended architectures. The extraordinary pace with which the research is growing in this field has resulted in an increasing number of new structures and frameworks compositions with many different potential applications. ${ }^{1}$

Structure predictability, an important requirement for the synthesis of functional materials with tailored properties, has been recently proved to be viable even in the realm of MOFs. The concept of rational design was developed by O'Keeffe et al. $^{2}$ and, as brilliantly described by Feréy in one of his reviews, ${ }^{3}$ was rooted in the fact that topochemically selected reactions govern the construction process of metal-organic frameworks in solvothermal reactions. This suggests that, with adequate synthetic conditions, targeted inorganic subunits may be obtained in a systematic way for the construction of a desired framework. Therefore, as soon as the chemical conditions associated with the existence of a parent structure are known, the modulation of pore size and walls decoration can be directly achieved through the modification of the length of the ligand or the introduction of different functionalities on its skeleton. This means that, in principle, it is possible to tune and study, within a single class of materials, those properties that are exclusively dependent on the modifications introduced on the organic bridge (i.e., pore size and shape, surface selectivity, uptake capacity, etc.). However, the number of possibilities of combining inorganic and organic moieties is immense, and the almost infinite variation on the nature of the linkers can provide either a series of isostructural compounds or, without neglecting the unexpected results of serendipity, even new structures. 4

Among the numerous ligands used in MOFs chemistry, carboxylate-based ones are a highly studied family, due to their straightforward availability and to the fact that they can be easily functionalized with groups of different nature, in terms of basicity, acidity, or polarity. ${ }^{5}$ Within the numerous examples reported in the literature, an exceptional one is the isoreticular series of IRMOFs 1-16, derived from the prototypic MOF-5 structure. ${ }^{6}$ Yaghi et al. demonstrated that the organic spacer of MOF-5 can be functionalized with many different substituents

Received: May 31, 2012

Published: July 5, 2012 
(such as $-\mathrm{Br},-\mathrm{NH}_{2},-\mathrm{OC}_{3} \mathrm{H}_{7}$, etc.) and the pore size of the framework can be expanded with longer molecular struts as, for example, biphenyl or tetrahydropyrene, with no changes in the underlying topology. ${ }^{7}$ A systematic investigation of the effects of tagging a given carboxylate linker was carried out also in the case of UiO-66, ${ }^{5 g, i}$ MIL-53, ${ }^{5 e, h}$ and MIL- $88 .{ }^{5 f}$ Also, due to such exceptional examples, porous metal-organic frameworks have been individuated as promising zeolite-analogous materials, because they are expected to be more designable in pore size and shape, as well as to exhibit a wide structural diversity. However, one of the main weaknesses of carboxylate-based MOFs is the lack of stability at moderately high temperatures, in the presence of moisture, in acid or basic media, and, sometimes, even in air, which limits their utility in industrial applications.

Recently, nitrogen-donor ligands have proved to be a valid alternative to oxygen-based ones. ${ }^{8}$ In this respect, during the last years, we have demonstrated that pyrazolate-based ligands can be successfully exploited for the synthesis of highly robust metal-organic frameworks. ${ }^{9}$ Within this class, the sodalite-type $\mathrm{Ni}_{3} \mathrm{BTP}_{2}\left[\mathrm{H}_{3} \mathrm{BTP}=1,3,5\right.$-tris $(1 \mathrm{H}$-pyrazol-4-yl $)$ benzene $]$ material $^{9 \mathrm{~d}}$ represents the first example of metal-organic framework exhibiting high surface area (up to $1900 \mathrm{~m}^{2} / \mathrm{g}$ ) and exposed metal sites coupled to a high thermal stability (up to $430{ }^{\circ} \mathrm{C}$ in air) and an exceptional resistance to hydrolysis and decomposition during treatment with hot water, acidic, and basic solutions.

Another important challenge in the field of porous polymers is the development of stable structures including functional organic sites (i) via direct assembly from inorganic nodes and tagged-organic linkers or (ii) via postsynthetic modification of the pores surface. ${ }^{10}$ However, in the direct-assembly approach, a functional group may be harder to incorporate, either because of its thermal instability under MOF synthesis conditions or due to unpredictable reaction pathways. In the light of the high stability of N-based ligands incorporated into a MOF structure, this class of linkers is expected to respond better than their Obased counterparts to the development of isoreticular series of MOFs including functional organic sites via direct assembly, with the final aim of tuning their pore properties (pore size, shape, volume, and decoration) as a mean of enhancing the uptake capacity and selectivity toward a targeted guest.

To the best of our knowledge, a systematic investigation within a nitrogen-based class of isoreticular MOFs is still missing. Therefore, given the remarkable results obtained with non functionalized pyrazolate-based linkers, we decided to investigate, for a given archetypical topology, how different functionalities on the same ligand can affect the chemical and physical properties of the corresponding MOF, with particular attention on estimating the trends of stability and adsorption properties versus the nature of the substituents. Accordingly, starting from 1,4-bis $\left(1 \mathrm{H}\right.$-pyrazol-4-yl)benzene $\left(\mathrm{H}_{2} \mathrm{BDP}\right)$, four new tagged linkers ( $\mathrm{H}_{2} \mathrm{BDP} \_\mathbf{X}$, Scheme $1, \mathrm{X}=\mathrm{NO}_{2}, \mathrm{NH}_{2}, \mathrm{OH}$, $\mathrm{SO}_{3} \mathrm{H}$ ) were prepared and employed, for the first time, for the systematic isolation and characterization of the two series of pyrazolate-based tagged frameworks MBDP_X $(M=N i, Z n)$, based on the skeleta of the parent NiBDP and ZnBDP materials (Figure 1). ${ }^{9 a}$ In the following, synthetic strategies toward the nitro, amino, hydroxyl, and sulfonic acid derivatives of $\mathrm{H}_{2} \mathrm{BDP}$ are reported. Moreover, reaction paths toward the corresponding MBDP_X MOFs, improved with respect to the original ones leading to NiBDP and ZnBDP, are proposed. The isostructural nature of NiBDP_X and ZnBDP_X was
Scheme 1. Synthesis of Tagged 1,4-Bis(1H-pyrazol-4yl)benzene Derivatives and Their Acronyms Used in This Work $\left(\mathrm{H}_{2} \mathrm{BDP} \_\mathrm{X}, \mathrm{X}=\mathrm{NO}_{2}, \mathrm{NH}_{2}, \mathrm{OH}, \mathrm{SO}_{3} \mathrm{H}\right)^{a}$



a (a) $\mathrm{H}_{2} \mathrm{SO}_{4} / \mathrm{HNO}_{3}, 1 \mathrm{~h}$, room temperature, then ice/water; (b) $\mathbf{H}_{2}$ BDP_ $\mathrm{NO}_{2}+\mathrm{NH}_{4} \mathrm{HCO}_{3}, \mathrm{Pd} / \mathrm{C}, \mathrm{N}, \mathrm{N}^{\prime}$-dimethylformamide, $110^{\circ} \mathrm{C}$, $2 \mathrm{~h}$, then ice/water; (c) $\mathbf{H}_{2} \mathbf{B D P} \mathbf{N H}_{2}+\mathrm{H}_{2} \mathrm{SO}_{4}, \mathrm{NaNO}_{2}$, then $\mathrm{H}_{2} \mathrm{SO}_{4}$ / water (1:1), $110{ }^{\circ} \mathrm{C}, 1 \mathrm{~h}$; (d) $\overline{\mathrm{H}}_{2} \mathrm{SO}_{4}$ (conc.), $1 \mathrm{~h}$, room temperature, then ice/water.

ascertained by means of X-ray powder diffraction (XRPD). Their thermal stability was evaluated by simultaneous TG/DSC analyses, while the effective presence of the functional sites was probed by FTIR. Variable-temperature X-ray powder diffraction experiments allowed one to study their structural response as a function of temperature and solvent content. Finally, their potential application in selective adsorption processes for gas separation and purification purposes of gases of environmental and industrial interest was investigated by conventional single component adsorption isotherms, as well as by advanced experiments of pulse gas chromatography and breakthrough curve measurements.

\section{EXPERIMENTAL DETAILS}

Synthesis and Characterization. All chemicals were obtained commercially and used without further purification. The 1,4-bis $(1 \mathrm{H}$ pyrazol-4-yl)benzene ligand $\left(\mathrm{H}_{2} \mathrm{BDP}\right)$ was prepared as described in the literature. ${ }^{11}$

2-Nitro[1,4-bis(1 $\mathrm{H}$-pyrazol-4-yl)benzene] $\left(\mathrm{H}_{2} \mathrm{BDP} \_\mathrm{NO}_{2}\right)$. 1,4$\operatorname{Bis}(1 H$-pyrazol-4-yl)benzene $(1.000 \mathrm{~g}, 4.76 \mathrm{mmol})$ was added in portions to concentrated sulfuric acid $(10 \mathrm{~mL})$ while keeping the reaction mixture cold with an ice bath. To the solution was then added $70 \%$ nitric acid $(0.255 \mathrm{~mL}, 5.71 \mathrm{mmol})$ dropwise while maintaining the reaction mixture cold. The ice bath was then removed, and the solution was left at room temperature under stirring for $1 \mathrm{~h}$. Next, $5 \mathrm{~g}$ of crushed ice was added, and the precipitate was filtered off and washed with $10 \mathrm{~mL}(2 \times 5 \mathrm{~mL})$ of water. The precipitate was neutralized with aqueous $\mathrm{NaHCO}_{3}$, and the resulting product was collected by filtration and washed with $10 \mathrm{~mL}$ of water $(2 \times 5 \mathrm{~mL})$, affording the pure ligand as a yellow solid $(1.03 \mathrm{~g}$, yield $85 \%) .{ }^{1} \mathrm{H}$ NMR (DMSO- $\left.d_{6}\right): \delta 7.63(\mathrm{~d}, J=8.2 \mathrm{~Hz}, 1 \mathrm{H}), 7.79(\mathrm{~s}, 2 \mathrm{H}), 7.89(\mathrm{dd}, J$ $=8.2,1.8 \mathrm{~Hz}, 1 \mathrm{H}), 8.08(\mathrm{~d}, J=1.8 \mathrm{~Hz}, 1 \mathrm{H}), 8.23(\mathrm{~s}, 2 \mathrm{H})$. IR (nujol): 3164(br), 1580(s), 1522(vs), 1350(vs), 1256(w), 1175(w), 1151(w), 1041(s), 976(w), 947(s), 894(w), 865(w), 815(s), 741(w), 664(w) $\mathrm{cm}^{-1}$. Anal. Calcd for $\mathrm{C}_{12} \mathrm{H}_{9} \mathrm{~N}_{5} \mathrm{O}_{2}\left(M_{\mathrm{w}}=255.2 \mathrm{~g} / \mathrm{mol}\right): \mathrm{C}, 56.47 ; \mathrm{H}$, 3.55; N, 27.44. Found: C, 55.7; H, 3.26; N, 26.37.

2-Amino[1,4-bis(1H-pyrazol-4-yl)benzene] $\left(\mathrm{H}_{2} \mathrm{BDP} \_\mathrm{NH}_{2}\right)$. To a suspension of $\mathbf{H}_{2}$ BDP_NO $\mathrm{NO}_{2}(0.300 \mathrm{~g}, 1.176 \mathrm{mmol})$ in DMF $(5 \mathrm{~mL})$ was added ammonium formate $(0.370 \mathrm{mg}, 5.873 \mathrm{mmol})$ at room temperature. The reaction mixture was then heated to $120{ }^{\circ} \mathrm{C}$, and $\mathrm{Pd} / \mathrm{C}(5 \%, 30 \mathrm{mg})$ was added in small portions. The final mixture was 
a) ZnBDP
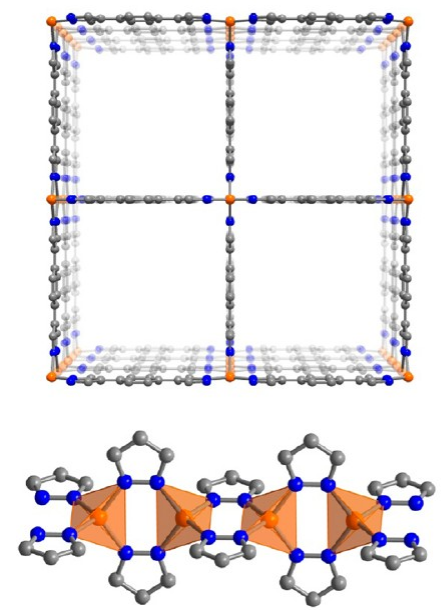

b) NiBDP
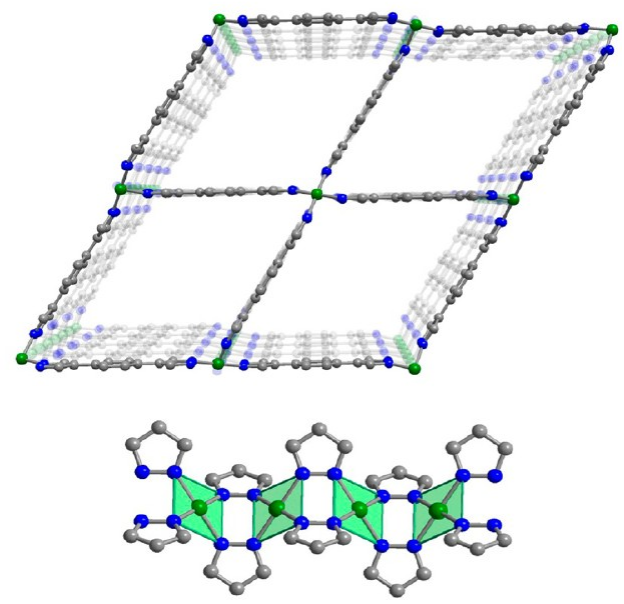

Figure 1. Top: Schematic drawing of the parent structures of ZnBDP and NiBDP $\left[\mathrm{H}_{2} \mathrm{BDP}=1\right.$,4-bis(1H-pyrazol-4-yl)benzene] highlighting their square and rhombic lattices, respectively. Bottom: A portion of their polymeric chains evidencing the local sterochemistries at the metal ions.

then kept under stirring at $100{ }^{\circ} \mathrm{C}$ for $2 \mathrm{~h}$. After the reaction mixture became clear, it was filtered through the pad of Celite. The Celite was then washed with a small amount of DMF, and the filtrate was diluted with crushed ice $(5 \mathrm{~g})$. The obtained precipitate was then filtered off and washed with water $(2 \times 5 \mathrm{~mL})$, affording a white powder of pure $\mathbf{H}_{2} \mathbf{B D P} \mathbf{N H}_{2}$ product $\left(250 \mathrm{mg}\right.$, yield $94 \%$ ). ${ }^{1} \mathrm{H}$ NMR (DMSO- $d_{6}$ ): $\delta$ $4.77(\mathrm{~s}, \overline{2} \mathrm{H}), 6.84(\mathrm{dd}, J=7.8,1.7 \mathrm{~Hz}, 1 \mathrm{H}), 6.97(\mathrm{~d}, J=1.7 \mathrm{~Hz}, 1 \mathrm{H})$, 7.15 (d, $J=7.8 \mathrm{~Hz}, 1 \mathrm{H}), 7.86$ (br s, 4H), 12.88 (br s, 2H). IR (nujol): 3420(s), 3338(s), 3111(br), 1621(s), 1575(s), 1522(w), 1334(w), 1290(w), 1169(vs), 1042(s), 988(w), 961(s), 946(w), 880(w), 864(s), 805(vs), 721(w), 660(w), 627(w) $\mathrm{cm}^{-1}$. Anal. Calcd for $\mathrm{C}_{12} \mathrm{H}_{11} \mathrm{~N}_{5}$ $\left(M_{\mathrm{w}}=225.2 \mathrm{~g} / \mathrm{mol}\right): \mathrm{C}, 63.99 ; \mathrm{H}, 4.92 ; \mathrm{N}, 31.09$. Found: C, 63.31; H, 5.42; N, 31.30 .

2-Hydroxo[1,4-bis(1H-pyrazol-4-yl)benzene] ( $\left.\mathrm{H}_{2} \mathrm{BDP} \_\mathrm{OH}\right)$. One gram $(4.444 \mathrm{mmol})$ of $\mathbf{H}_{2} \mathbf{B D P} \mathbf{N H}_{2}$ was dissolved in $5 \mathrm{~mL}$ of sulfuric acid. The mixture was stirred until a thick paste was formed. To this was added about $3 \mathrm{~g}$ of crushed ice, and the mixture was then kept in an ice bath. In a separate beaker, $\mathrm{NaNO}_{2}(0.440 \mathrm{~g}, 5.176$ $\mathrm{mmol}$ ) was dissolved in $4 \mathrm{~mL}$ of water. This solution was cooled and added dropwise, with constant stirring, to the acid amine solution. In a separate flask, a solution of $\mathrm{H}_{2} \mathrm{SO}_{4}(3 \mathrm{~mL})$ and water $(3 \mathrm{~mL})$ was heated to $110{ }^{\circ} \mathrm{C}$, and the entire diazonium salt solution was added dropwise. After the addition was over, the solution was allowed to boil for another $30 \mathrm{~min}$. It was then cooled with an ice bath, and the precipitate was filtered off and suspended in a solution of $\mathrm{NaHCO}_{3}$ in water and stirred for $2 \mathrm{~h}$ at $80{ }^{\circ} \mathrm{C}$. The yellowish precipitate was then filtered off, washed with water $(2 \times 5 \mathrm{~mL})$, and dried under vacuum (0.763 g, yield 76\%). ${ }^{1} \mathrm{H}$ NMR (DMSO- $\left.d_{6}\right): \delta 7.04(\mathrm{~m}, 2 \mathrm{H}), 7.51(\mathrm{~d}, J$ $=7.8 \mathrm{~Hz}, 1 \mathrm{H}), 8.04(\mathrm{br} \mathrm{s}, 4 \mathrm{H}), 9.67(\mathrm{~s}, 1 \mathrm{H}), 12.83(\mathrm{br} \mathrm{s}, 2 \mathrm{H})$. IR (nujol): 3525(s), 3387(br), 3182(br), 1621(w), 1588(s), 1563(w), 1534(w), 1440(s), 1346(w), 1274(w), 1254(w), 1216(w), 1160(vs), $1106(\mathrm{w}), 1036(\mathrm{~s}), 959(\mathrm{~s}), 948(\mathrm{~s}), 888(\mathrm{w}), 865(\mathrm{w}), 834(\mathrm{w}), 817(\mathrm{~s})$, 736(w), 670(w) $\mathrm{cm}^{-1}$. Anal. Calcd for $\mathrm{C}_{12} \mathrm{H}_{10} \mathrm{~N}_{4} \mathrm{O}\left(M_{\mathrm{w}}=226.2 \mathrm{~g} /\right.$ mol): C, 63.71; H, 4.46; N, 24.76. Found: C, 62.41; H, 5.11; N, 24.50.

2,5-Di(1 H-pyrazol-4-yl)benzenesulfonic Acid ( $\left.\mathrm{H}_{2} \mathrm{BDP} \_\mathrm{SO}_{3} \mathrm{H}\right)$. 1,4-Bis(1H-pyrazol-4-yl)benzene ( $1 \mathrm{~g}, 4.76 \mathrm{mmol}$ ) was added in portions to fuming sulfuric acid $(10 \mathrm{~mL})$ and was stirred for $1 \mathrm{~h}$ at room temperature. To the resulting solution was added crushed ice slowly to give a white precipitate that was filtered off, washed thoroughly with water $(2 \times 10 \mathrm{~mL})$, and dried under vacuum to give pure $\mathbf{H}_{2}$ BDP_SO ${ }_{3} \mathbf{H}\left(0.953 \mathrm{~g}\right.$, yield 69\%). ${ }^{1} \mathrm{H}$ NMR (DMSO- $\left.d_{6}\right): \delta$ $3.16(\mathrm{~s}, 1 \mathrm{H}), \overline{7} .48(\mathrm{~d}, J=8 \mathrm{~Hz}, 1 \mathrm{H}), 7.61(\mathrm{dd}, J=8,1.9 \mathrm{~Hz}, 1 \mathrm{H}), 8.11$ (s, $2 \mathrm{H}), 8.15$ (d, $J=1.9 \mathrm{~Hz}, 1 \mathrm{H}), 8.58$ (s, 2H). IR (nujol): 3415(br), 3174(br), 1580(w), 1564(w), 1511(w), 1346(w), 1311(w), 1256(w), 1215(vs), 1176(vs), 1113(s), 1084(s), 1047(s), 1026(s), 969(w), 943(w), 886(w), 831(s), 737(w), 682(w), 656(w) $\mathrm{cm}^{-1}$. Anal. Calcd for $\mathrm{C}_{12} \mathrm{H}_{10} \mathrm{~N}_{4} \mathrm{O}_{3} \mathrm{~S}\left(M_{\mathrm{w}}=290.3 \mathrm{~g} / \mathrm{mol}\right): \mathrm{C}, 49.65 ; \mathrm{H}, 3.47 ; \mathrm{N}, 19.30$. Found: C, 49.84; H, 3.97; N, 18.64 .

General Procedure for NiBDP_X (X $\left.=\mathrm{H}, \mathrm{NO}_{2}, \mathrm{NH}_{2}, \mathrm{OH}\right)$ Preparation. $\mathbf{H}_{2}$ BDP_X $(0.5 \mathrm{mmol})$ was dissolved in DMF $(10 \mathrm{~mL})$ in a $50 \mathrm{~mL}$ Schlenk flask and heated to $60{ }^{\circ} \mathrm{C}$. $\mathrm{Ni}\left(\mathrm{CH}_{3} \mathrm{COO}\right)_{2} \cdot 4 \mathrm{H}_{2} \mathrm{O}$ $(0.5 \mathrm{mmol})$ was then added to the solution under stirring. The mixture was allowed to react for $5 \mathrm{~h}$ at reflux. After being cooled to room temperature, the orange solid was collected by filtration, washed with methanol $(3 \times 10 \mathrm{~mL})$, and dried under vacuum. Yields typically fall in the $50-70 \%$ range, depending on the amount of entrapped solvent and on the performances of the filtration processes, heavily conditioned by the crystal sizes.

Anal. Calcd for $\mathrm{Ni}\left(\mathrm{C}_{12} \mathrm{H}_{7} \mathrm{~N}_{5} \mathrm{O}_{2}\right)\left(\mathrm{C}_{3} \mathrm{H}_{7} \mathrm{NO}\right)_{2}\left(\mathrm{CH}_{3} \mathrm{OH}\right)_{2}$ (NiBDP $\left.\mathrm{NO}_{2}\right)\left(M_{\mathrm{w}}=522 \mathrm{~g} / \mathrm{mol}\right): \mathrm{C}, 46.00 ; \mathrm{H}, 5.60 ; \mathrm{N}, 18.78$. Found: $\overline{\mathrm{C}}$, 45.96; H, 5.45; N, 19.28. IR (nujol): 1676(vs), 1649(vs), 1571(s), 1523(s), 1256(vs), 1179(w), 1136(w), 1107(w), 1062(s), 1006(w), 982(w), 955(w), 869(w), 837(w), 762(w), 738(w), 673(w) $\mathrm{cm}^{-1}$.

Anal. Calcd for $\mathrm{Ni}\left(\mathrm{C}_{12} \mathrm{H}_{9} \mathrm{~N}_{5}\right)\left(\mathrm{C}_{3} \mathrm{H}_{7} \mathrm{NO}\right)\left(\mathrm{H}_{2} \mathrm{O}\right)\left(\mathrm{CH}_{3} \mathrm{OH}\right)$ $\left(\right.$ NiBDP_NH $\left.\mathbf{N H}_{2}\right)\left(M_{\mathrm{w}}=405 \mathrm{~g} / \mathrm{mol}\right): \mathrm{C}, 47.44 ; \mathrm{H}, 5.47 ; \mathrm{N}, 20.75$. Found: $\bar{C}, 47.80 ; \mathrm{H}, 5.95 ; \mathrm{N}, 21.05$. IR (nujol): 3437(s), 3355(s), $1654(\mathrm{~s}), 1620(\mathrm{w}), 1573(\mathrm{~s}), 1346(\mathrm{w}), 1262(\mathrm{w}), 1169(\mathrm{w}), 1134(\mathrm{w})$, 1064(s), 954(s), 855(w), 810(w), 722(w) $\mathrm{cm}^{-1}$.

Anal. Calcd for $\mathrm{Ni}\left(\mathrm{C}_{12} \mathrm{H}_{8} \mathrm{~N}_{4} \mathrm{O}\right)\left(\mathrm{H}_{2} \mathrm{O}\right)_{3}\left(\mathrm{CH}_{3} \mathrm{OH}\right)$ (NiBDP_OH) $\left(M_{\mathrm{w}}=369 \mathrm{~g} / \mathrm{mol}\right): \mathrm{C}, 42.31 ; \mathrm{H}, 4.92 ; \mathrm{N}, 15.18$. Found: C, 41.99; H, 4.81; N, 15.39. IR (nujol): 3579(s), 1619(w), 1577(s), 1269(w), $1222(\mathrm{w}), 1175(\mathrm{w}), 1147(\mathrm{w}), 1064(\mathrm{~s}), 955(\mathrm{~s}), 866(\mathrm{w}), 843(\mathrm{w})$, 813(w), $722(\mathrm{w}) \mathrm{cm}^{-1}$.

General Procedure for ZnBDP_X (X $\left.=\mathrm{H}, \mathrm{NO}_{2}, \mathrm{NH}_{2}, \mathrm{OH}\right)$ Preparation. $\mathrm{H}_{2} \mathrm{BDP} \mathbf{X}(0.5 \mathrm{mmol})$ was dissolved in DMF $(10 \mathrm{~mL})$ in a $50 \mathrm{~mL}$ Schlenk flask and heated to $60{ }^{\circ} \mathrm{C}$. $\mathrm{Zn}\left(\mathrm{CH}_{3} \mathrm{COO}\right)_{2} \cdot 2 \mathrm{H}_{2} \mathrm{O}$ $(0.5 \mathrm{mmol})$ was then added to the solution under stirring. The mixture was allowed to react for $5 \mathrm{~h}$ at reflux. After being cooled to room temperature, the white solid was collected by filtration, washed with methanol $(3 \times 10 \mathrm{~mL})$, and dried under vacuum. Yields typically fall in the $50-70 \%$ range, depending on the amount of entrapped solvent and on the performances of the filtration processes, heavily conditioned by the crystal sizes.

Anal. Calcd for $\mathrm{Zn}\left(\mathrm{C}_{12} \mathrm{H}_{7} \mathrm{~N}_{5} \mathrm{O}_{2}\right)\left(\mathrm{C}_{3} \mathrm{H}_{7} \mathrm{NO}\right)_{2}\left(\mathrm{CH}_{3} \mathrm{OH}\right)_{2}\left(\mathrm{H}_{2} \mathrm{O}\right)_{5}$ $\left(Z n B D P \_N_{2}\right)\left(M_{w}=619 \mathrm{~g} / \mathrm{mol}\right): \mathrm{C}, 38.81 ; \mathrm{H}, 6.35 ; \mathrm{N}, 15.84$. Found: $\mathrm{C}, 38.63 ; \mathrm{H}, 6.03 ; \mathrm{N}, 16.06$. IR (nujol): 3350(br), 1670(vs), 1578(s), 1527(s), 1532(w), 1257(vs), 1134(w), 1092(w), 1064(s), 1012(w), 982(w), 954(w), 869(w), 847(w), 764(w), 739(w), 722(w), 659(w), 623(w) $\mathrm{cm}^{-1}$.

Anal. Calcd for $\mathrm{Zn}\left(\mathrm{C}_{12} \mathrm{H}_{9} \mathrm{~N}_{5}\right)\left(\mathrm{C}_{3} \mathrm{H}_{7} \mathrm{NO}\right)_{2}\left(\mathrm{CH}_{3} \mathrm{OH}\right)\left(\mathrm{H}_{2} \mathrm{O}\right)$ $\left(\right.$ ZnBDP_NH NH $\left._{2}\right)\left(M_{\mathrm{w}}=484.8 \mathrm{~g} / \mathrm{mol}\right): \mathrm{C}, 47.07 ; \mathrm{H}, 6.03 ; \mathrm{N}, 20.22$. Found: $\bar{C}, 47.33$; H, 5.74; N, 20.07. IR (nujol): 3409(w), 3341(w), 1675(vs), 1629(w), 1571(s), 1402(w), 1344(w), 1256(s), 1177(w), 
Table 1. Unit Cell Parameters ${ }^{a}$ of MBDP_X Materials in Their As-Synthesized $\left(30^{\circ} \mathrm{C}\right)$, Evacuated $\left(300{ }^{\circ} \mathrm{C}\right)$, and Back-Solvated $\left(30{ }^{\circ} \mathrm{C}+\mathrm{DMF}\right)$ Forms

\begin{tabular}{|c|c|c|c|c|c|c|c|c|c|c|c|c|c|}
\hline & \multirow[b]{2}{*}{ S.G. } & \multicolumn{4}{|c|}{$30{ }^{\circ} \mathrm{C}$} & \multicolumn{4}{|c|}{$300{ }^{\circ} \mathrm{C}$} & \multicolumn{4}{|c|}{$30^{\circ} \mathrm{C}+\mathrm{DMF}$} \\
\hline & & $a, \AA$ & $b, \AA$ & $c, \AA$ & $V, \AA^{3}$ & $a, \AA$ & $b, \AA$ & $c, \AA$ & $V, \AA^{3}$ & $a, \AA$ & $b, \AA$ & $c, \AA$ & $V, \AA^{3}$ \\
\hline $\mathrm{NiBDP} \mathrm{NO}_{2}$ & Imma & 7.06 & 22.88 & 13.74 & 2222.38 & 6.88 & 23.4 & 13.25 & 2135.04 & 7.05 & 22.85 & 13.78 & 2219.30 \\
\hline $\mathrm{NiBDP} \mathrm{NH}_{2}$ & Imma & 6.93 & 22.32 & 14.32 & 2214.68 & 6.70 & 23.10 & 12.62 & 1953.99 & 6.93 & 22.38 & 14.27 & 2213.65 \\
\hline NiBDP_OH & Imma & 6.80 & 22.04 & 14.62 & 2190.51 & 6.63 & 22.68 & 13.59 & 2045.01 & 6.83 & 22.19 & 14.56 & 2209.37 \\
\hline $\mathrm{ZnBDP} \mathrm{NO}_{2}$ & $\mathrm{Cccm}$ & 18.30 & 19.21 & 7.41 & 2606.67 & 14.66 & 21.21 & 7.18 & 2232.09 & 18.25 & 19.21 & 7.39 & 2594.52 \\
\hline $\mathrm{ZnBDP} \mathrm{NH}_{2}{ }^{b}$ & $\mathrm{Cccm}$ & 18.39 & 19.12 & 7.35 & 2585.68 & n.a. & n.a. & n.a. & n.a. & 18.21 & 19.33 & 7.34 & 2587.25 \\
\hline ZnBDP_OH & $\mathrm{Cccm}$ & 17.82 & 19.70 & 7.22 & 2535.55 & 17.07 & 20.55 & 6.99 & 2454.19 & 17.88 & 19.68 & 7.19 & 2532.70 \\
\hline
\end{tabular}


${ }^{b}$ The very low crystallinity of HT ZnBDP_NH $\mathbf{N H}_{2}$ prevented treatment of its XRPD data.

1131(s), 1091(w), 1060(s), 1012(w), 995(w), 951(s), 856(w), 810(w), 724(w), 662(w) $\mathrm{cm}^{-1}$

Anal. Calcd for $\mathrm{Zn}\left(\mathrm{C}_{12} \mathrm{H}_{8} \mathrm{~N}_{4} \mathrm{O}\right)\left(\mathrm{C}_{3} \mathrm{H}_{7} \mathrm{NO}\right)_{2}\left(\mathrm{CH}_{3} \mathrm{OH}\right)$ $($ ZnBDP OH $)\left(M_{\mathrm{w}}=467.8 \mathrm{~g} / \mathrm{mol}\right): \mathrm{C}, 48.78 ; \mathrm{H}, 5.60 ; \mathrm{N}, 17.96$. Found: $\bar{C}$, 48.63; H, 5.98; N, 18.29. IR (nujol): 3470(br), 1675(vs), 1575(s), 1354(w), 1254(s), 1223(w), 1170(w), 1141(w), 1125(w), 1102(w), 1058(s), 1013(w), 955(w), 867(w), 840(w), 814(w), $720(\mathrm{w}), 663(\mathrm{w}), 603(\mathrm{w}) \mathrm{cm}^{-1}$

Synthesis of $\mathrm{Ni}\left(\mathrm{C}_{12} \mathrm{H}_{9} \mathrm{~N}_{4} \mathrm{SO}_{3}\right)_{2}\left(\mathrm{C}_{3} \mathrm{H}_{7} \mathrm{NO}\right)_{2}, \mathrm{NiBDP} \_\mathrm{SO}_{3} \mathrm{H}$. $\mathrm{H}_{2}$ BDP_SO ${ }_{3} \mathrm{H}(0.050 \mathrm{~g}, 0.172 \mathrm{mmol})$ was dissolved in DMSO (3 $\mathrm{mL}$ ) in a $50 \mathrm{~mL}$ Schlenk flask, and DMF $(3 \mathrm{~mL})$ was added to this solution. The mixture was heated to $60{ }^{\circ} \mathrm{C}$, and $\mathrm{Ni}\left(\mathrm{CH}_{3} \mathrm{COO}\right)_{2} \cdot 4 \mathrm{H}_{2} \mathrm{O}$ $(0.085 \mathrm{~g}, 0.5 \mathrm{mmol})$ was added under stirring. The mixture was then allowed to react for $5 \mathrm{~h}$ at $160{ }^{\circ} \mathrm{C}$. After being cooled at room temperature, the yellowish solid was collected by filtration, washed with DMF $(3 \times 10 \mathrm{~mL})$, and dried under vacuum. Anal. Calcd for $\mathrm{Ni}\left(\mathrm{C}_{12} \mathrm{H}_{9} \mathrm{~N}_{4} \mathrm{SO}_{3}\right)_{2}\left(\mathrm{C}_{3} \mathrm{H}_{7} \mathrm{NO}\right)_{2}\left(M_{\mathrm{w}}=785.48 \mathrm{~g} / \mathrm{mol}\right): \mathrm{C}, 45.87 ; \mathrm{H}$, 4.36; N, 17.83. Found: C, 46.34; H, 4.85; N, 17.35. IR (nujol): 3442(s), 3159(w), 1666(s), 1590(w), 1572(w), 1251(s), 1158(s), 1080(w), 1053(w), 1022(s), 961(w), 854(w), 790(w), 721(w), 691(w), 823(w) $\mathrm{cm}^{-1}$.

X-ray Powder Diffraction Structural Analysis (XRPD). A powdered, microcrystalline sample of DMF-solvated NiBDP_SO ${ }_{3} \mathrm{H}$ (NiBDP $\mathrm{SO}_{3} \mathbf{H} \cdot 2 \mathrm{DMF}$ ) was deposited in the hollow of an aluminum sample holder equipped with a zero-background plate. As the compound is poorly stable at ambient conditions, due to quick solvent release, numerous attempts were preliminary carried out to find proper measurement settings: with our setup, solvent loss was invariably faster than the time scale of the XRPD acquisition. The best compromise between a limited solvent loss and data of sufficient quality to allow a structural analysis was found collecting only in the $6-55^{\circ} 2 \theta$ range $\left(\Delta 2 \theta=0.02^{\circ}, 1 \mathrm{~h}\right.$ scan $)$. Data collections were performed on a Bruker AXS D8 Advance diffractometer, equipped with a linear position-sensitive Lynxeye detector, primary beam Soller slits, and Ni-filtered $\mathrm{Cu} \mathrm{K} \alpha$ radiation $(\lambda=1.5418 \AA$ ) $)$. Generator setting: $40 \mathrm{kV}, 40 \mathrm{~mA}$. Standard peak search, followed by indexing with TOPAS, ${ }^{12}$ allowed the detection of approximate unit cell parameters: monoclinic $P, a=7.52 \AA, b=16.32 \AA, c=17.60 \AA, \beta=$ $94.17^{\circ}, V=2155.63 \AA^{3}$, and $\mathrm{GOF}=17.5$. The space group $P 2_{1} / c$ was assigned on the basis of the systematic absence conditions and was later confirmed by a Le Bail refinement. Structure solution was performed by the simulated annealing technique, as implemented in TOPAS, using for $\mathbf{H}_{2} \mathbf{B D P} \mathrm{SO}_{3} \mathrm{H}$ and DMF rigid, idealized models. The final refinement was carried out by the Rietveld method, maintaining the rigid bodies introduced at the structure solution stage. The background was modeled by a polynomial function of the Chebyshev type. One, refined, isotropic thermal parameter was assigned to the metal atoms, augmented by $2.0 \AA^{2}$ for lighter atoms.

For the other two structures reported below (the NiBDP_SO ${ }_{3} \mathrm{H} \cdot \mathrm{DMF}$ and NiBDP_SO $\mathrm{SO}_{3} \mathrm{H}$ species), an identical procedure was applied to diffractograms collected at 90 and $250{ }^{\circ} \mathrm{C}$, for which the same apparatus used for the variable-temperature experiments was adopted. For these experiments, overnight data collections were performed in the ranges $6-70^{\circ}$ and $7-35^{\circ} 2 \theta\left(\Delta 2 \theta=0.02^{\circ}\right)$, respectively. The final Rietveld refinement plots for the three compounds are shown in Figure $S 1$.

Crystal Data for Ni( $\left.\mathrm{H}_{2} B D P_{-} \mathrm{SO}_{3}\right)_{2} \cdot 2 \mathrm{DMF} . \mathrm{C}_{30} \mathrm{H}_{32} \mathrm{~N}_{10} \mathrm{NiO}_{8} \mathrm{~S}_{2}, M_{\mathrm{w}}=$ $783.46 \mathrm{~g} / \mathrm{mol}$, monoclinic, $P 2_{1} / c, a=7.526(1) \AA, b=16.343(4) \AA, c=$ 17.631(5) $\AA$, $\beta=94.07(2)^{\circ}, V=2163.1(9) \AA^{3} ; Z=2 ; \rho_{\text {calc }}=1.20 \mathrm{~g}$ $\mathrm{cm}^{-3} ; F(000)=782 ; \mu(\mathrm{Cu} \mathrm{K} \alpha)=20.0 \mathrm{~cm}^{-1} . R_{\mathrm{p}}, R_{\mathrm{wp}}$, and $R_{\mathrm{Bragg}}$ are 0.046, 0.062, and 0.051, respectively, for 29 parameters.

Crystal Data for $\mathrm{Ni}\left(\mathrm{H}_{2} \mathrm{BDP} \mathrm{SO}_{3}\right)_{2}$. DMF. $\mathrm{C}_{27} \mathrm{H}_{25} \mathrm{~N}_{9} \mathrm{NiO}_{7} \mathrm{~S}_{2}, M_{\mathrm{w}}=$ $710.37 \mathrm{~g} / \mathrm{mol}$, monoclinic, $P 2_{1} / c, a=7.4533(4) \AA, b=15.005(1) \AA, c$ $=17.611(3) \AA, \beta=91.293(6)^{\circ}, V=1969.0(4) \AA^{3} ; Z=2 ; \rho_{\text {calc }}=1.21 \mathrm{~g}$ $\mathrm{cm}^{-3} ; F(000)=732 ; \mu(\mathrm{Cu} \mathrm{K} \alpha)=21.1 \mathrm{~cm}^{-1} . R_{\mathrm{p}}, R_{\mathrm{wp}}$, and $R_{\mathrm{Bragg}}$ are $0.019,0.028$, and 0.009 , respectively, for 52 parameters.

Crystal Data for $\mathrm{Ni}\left(\mathrm{H}_{2} \mathrm{BDP} \mathrm{SO}_{3}\right)_{2} \cdot \mathrm{C}_{24} \mathrm{H}_{18} \mathrm{~N}_{8} \mathrm{NiO}_{6} \mathrm{~S}_{2}, M_{\mathrm{w}}=637.27$ $\mathrm{g} / \mathrm{mol}$, monoclinic, $P 2_{1} / c, a=7.4594(5) \AA, b=15.589(2) \AA, c=$ 17.151(3) $\AA, \beta=91.648(8)^{\circ}, V=1993.6(4) \AA^{3} ; Z=2 ; \rho_{\text {calc }}=1.06 \mathrm{~g}$ $\mathrm{cm}^{-3} ; F(000)=652 ; \mu(\mathrm{Cu} \mathrm{K} \alpha)=20.2 \mathrm{~cm}^{-1} . R_{\mathrm{p}}, R_{\mathrm{wp}}$, and $R_{\mathrm{Bragg}}$ are $0.0245,0.033$, and 0.011 , respectively, for 37 parameters. Crystallographic data (excluding structure factors) for the structures reported in this Article have been deposited with the Cambridge Crystallographic Data Centre as supplementary publication nos. CCDC 884528884530. Copies of the data can be obtained free of charge on application to CCDC, 12 Union Road, Cambridge CB2 1EZ, UK (fax, +44 1223336 033; e-mail, deposit@ccdc.cam.ac.uk).

Variable-Temperature X-ray Powder Diffraction. Thermodiffractometric experiments were performed on the as-synthesized NiBDP_SO $\mathrm{S}_{3} \mathrm{H} \cdot 2 \mathrm{DMF}$ sample to highlight its "structural" response to temperature changes. A powdered batch of the sample was deposited in the hollow of an aluminum sample holder, assembled by Officina Elettrotecnica di Tenno, Ponte Arche, Italy; diffractograms were acquired in air from $30{ }^{\circ} \mathrm{C}$ to the loss of crystallinity, with steps of $20{ }^{\circ} \mathrm{C}$, in a significant low-angle $2 \theta$ range $\left(7-22^{\circ}\right)$. Le Bail refinements were carried out to derive the lattice constants, later employed in the rationalization of the thermal properties. By means of the same apparatus, another set of experiments was performed on all series of MBDP_X materials $\left(\mathrm{M}=\mathrm{Ni}^{2+}, \mathrm{Zn}^{2+} ; \mathrm{X}=\mathrm{NO}_{2}, \mathrm{NH}_{2}, \mathrm{OH}\right)$ : for each species, starting from a freshly prepared batch, three diffractograms were acquired in isothermal conditions at 30,300, and back to $30{ }^{\circ} \mathrm{C}$ with further solvation of the material with $N, N^{\prime}$ dimethylformamide. The data were then treated by the Le Bail refinement method to derive the corresponding unit cell parameters (Table 1).

Gas Adsorption Measurements. Conventional adsorption isotherms were measured using a Micromeritics Tristar 3000 volumetric instrument under continuous adsorption conditions. Brunauer-Emmet-Teller (BET) and Langmuir analyses were carried out to determine the total specific surface areas for the $\mathrm{N}_{2}$ isotherms at $77 \mathrm{~K}$. In addition, $\mathrm{CO}_{2}$ isotherms at $273 \mathrm{~K}$ were measured to evaluate the micropore region by means of the Dubinin-Radushkevich equation (Table 2). Prior to measurement, powdered samples were heated at $453 \mathrm{~K}$ for $12 \mathrm{~h}$ and outgassed to $10^{-6}$ Torr.

Variable-Temperature Pulse Gas Chromatography. Gasphase adsorption at zero coverage surface was studied using the pulse chromatographic technique, ${ }^{13}$ employing a gas chromatograph (Varian 450-GC) equipped with a $15 \mathrm{~cm}$-column $(0.4 \mathrm{~cm}$ internal 
Table 2. Langmuir, BET $\left(\mathrm{N}_{2}, 77 \mathrm{~K}\right)$, and Dubinin-

Radushkevich $\left(\mathrm{CO}_{2}, 273 \mathrm{~K}\right)$ Specific Surface Areas for the Two Series NiBDP_X and ZnBDP_X $\left(\mathrm{X}=\mathrm{H}, \mathrm{NO}_{2}, \mathrm{NH}_{2}\right.$, $\left.\mathrm{OH}, \mathrm{SO}_{3} \mathrm{H}\right)$ Desolvated under Reduced Pressure at $180{ }^{\circ} \mathrm{C}$ for $12 \mathrm{~h}$

\begin{tabular}{lccr} 
& $\mathrm{SA}_{\mathrm{BET}} / \mathrm{m}^{2} \mathrm{~g}^{-1}$ & $\mathrm{SA}_{\text {Langmuir }} / \mathrm{m}^{2} \mathrm{~g}^{-1}$ & $\mathrm{SA}_{\mathrm{DR}} / \mathrm{m}^{2} \mathrm{~g}^{-1}$ \\
NiBDP & $1066(18)$ & $1350(9)$ & $1480(10)$ \\
NiBDP_NO & $1131(17)$ & $1423(9)$ & $2350(4)$ \\
NiBDP_NH & $1305(22)$ & $1645(8)$ & $990(2)$ \\
NiBDP_OH & $1103(18)$ & $1394(10)$ & $1980(7)$ \\
NiBDP_SO & $819(16)$ & $1044(6)$ & $1220(9)$ \\
ZnBDP & $2288(41)$ & $2857(2)$ & $1220(11)$ \\
ZnBDP_NO & $1875(52)$ & $2358(5)$ & $710(3)$ \\
ZnBDP_NH & $1345(21)$ & $1788(78)$ & $670(9)$ \\
ZnBDP_OH & $1170(22)$ & $1484(7)$ & $1420(4)$ \\
\hline
\end{tabular}

diameter) packed with ca. $1 \mathrm{~g}$ of pelletized sample (particles size 0.5 $\mathrm{mm}$ ). To avoid pressure drops in the chromatographic column, the particles were aggregated by emulsifying them in an aqueous suspension $(1 \mathrm{~mL})$ of starch $(0.1 \mathrm{~g})$ at $343 \mathrm{~K}$ for $1 \mathrm{~min}$. The solvent was then removed under reduced pressure, and the resulting solid was grounded through a $0.5 \mathrm{~mm}$ sieve to give the pelletized samples. For the activation of the material, a He flow $\left(30 \mathrm{~mL} \mathrm{~min}^{-1}\right)$ was passed through the column at $453 \mathrm{~K}$ for $7 \mathrm{~h}$. Later, $1 \mathrm{~mL}$ of an equimolecular gas mixture of $\mathrm{C}_{2} \mathrm{H}_{2}, \mathrm{H}_{2}, \mathrm{CH}_{4}$, and $\mathrm{CO}_{2}$ was injected at 1 bar on an $\mathrm{He}$ flow $\left(15 \mathrm{~mL} \mathrm{~min}{ }^{-1}\right)$. The separation performance of the chromatographic column was then examined at different temperatures (273$323 \mathrm{~K}$ ) by means of a mass spectrometer gas analysis system (Pfeiffer Vacoon), detecting ion peaks at $m / z 44\left(\mathrm{CO}_{2}\right), 26\left(\mathrm{C}_{2} \mathrm{H}_{2}\right), 16\left(\mathrm{CH}_{4}\right)$, $4(\mathrm{He})$, and $2\left(\mathrm{H}_{2}\right)$. The dead volume of the system was calculated using the retention time of hydrogen as a reference.

On the other hand, the retention time of $\mathrm{H}_{2} \mathrm{O}$ was determined at variable temperature $(363-473 \mathrm{~K})$ by using a thermal conductivity detector (TCD) of the gas chromatograph equipment, configured for this determination using an on-column injector $(0.2 \mu \mathrm{L})$.

Breakthrough Experiments for Gas Separation. The $15 \mathrm{~cm}$ chromatographic column, prepared as detailed above, was activated under a pure $\mathrm{He}$ flow $\left(30 \mathrm{~mL} \mathrm{~min}^{-1}\right)$ at $453 \mathrm{~K}$ for $7 \mathrm{~h}$ and then used for evaluating the $\mathrm{CO}_{2} / \mathrm{N}_{2}, \mathrm{CO}_{2} / \mathrm{CH}_{4}$, and $\mathrm{C}_{2} \mathrm{H}_{2} / \mathrm{CH}_{4}$ separation performances of the materials. The desired gas mixture $\left(10 \mathrm{~mL} \mathrm{~min}^{-1}\right)$ was prepared via mass flow controllers. For instance, $\mathrm{CO}_{2} / \mathrm{N}_{2}$ (0.14:0.86) mixtures were prepared to simulate the emission of flue gas from a power plant employing $1.4 \mathrm{~mL} \mathrm{~min}^{-1}$ of $\mathrm{CO}_{2}$ and $8.6 \mathrm{~mL}$ $\mathrm{min}^{-1}$ of $\mathrm{N}_{2}$ flows, and the breakthrough experiments were carried out at 273,303 , and $323 \mathrm{~K}$ by step changes from $\mathrm{He}$ to $\mathrm{CO}_{2} / \mathrm{N}_{2}$ flow mixtures. The relative amounts of gases passing through the column were monitored on a mass spectrometer gas analysis system (Pfeiffer Vacoon) detecting ion peaks at $m / z 44\left(\mathrm{CO}_{2}\right), 28\left(\mathrm{~N}_{2}\right)$, and $4(\mathrm{He})$.

Other Physical Measurements. Infrared (IR) spectra were acquired in transmission mode on a FTIR Shimadzu Prestige-21 spectrometer. The materials under study were mixed with nujol to form a mull and recorded with $\mathrm{KBr}$ plates in the spectral range 4000$600 \mathrm{~cm}^{-1}$. Simultaneous TG and DSC analyses were performed in a $\mathrm{N}_{2}$ stream on a Netzsch STA 409 PC Luxx with a heating rate of $10^{\circ} \mathrm{C}$ $\min ^{-1}$ to $900{ }^{\circ} \mathrm{C}$. Elemental analyses were carried out on a PerkinElmer CHN Analyzer 2400 Series II at the facility of the Università dell'Insubria in Como.

\section{RESULTS AND DISCUSSION}

Syntheses. The 1,4-bis(1H-pyrazol-4-yl)benzene ligand $\left(\mathrm{H}_{2} \mathrm{BDP}\right.$, Scheme 1) was chosen as parent skeleton for the preparation of a new series of functionalized linkers $\left(\mathrm{H}_{2}\right.$ BDP $\mathbf{X}$, Scheme 1) due to its easy availability from synthesis, in good yields and in gram scale. ${ }^{11}$ The first functional group introduced on the aromatic spacer was the nitro group: to isolate 2-nitro[1,4-bis( $1 H$-pyrazol-4-yl)benzene], $\mathrm{H}_{2} \mathbf{B D P} \mathrm{NO}_{2}$, a simple nitration in sulfuric and nitric acid mixtures was performed. ${ }^{14}$ Next, reduction of the nitro group yielded 2-amino[1,4-bis $(1 \mathrm{H}$-pyrazol-4-yl)benzene], $\mathbf{H}_{2}$ BDP_NH ${ }_{2}{ }^{15}$ Because of the low solubility of $\mathbf{H}_{2} \mathbf{B D P} \mathbf{N O}_{2}$, the reduction was carried out in $N, N^{\prime}$-dimethylformamide rather than in an alcoholic solution. ${ }^{16}$ Subsequently, by exploiting the reactivity of diazonium salts, readily available through primary aromatic amines, the amino group was

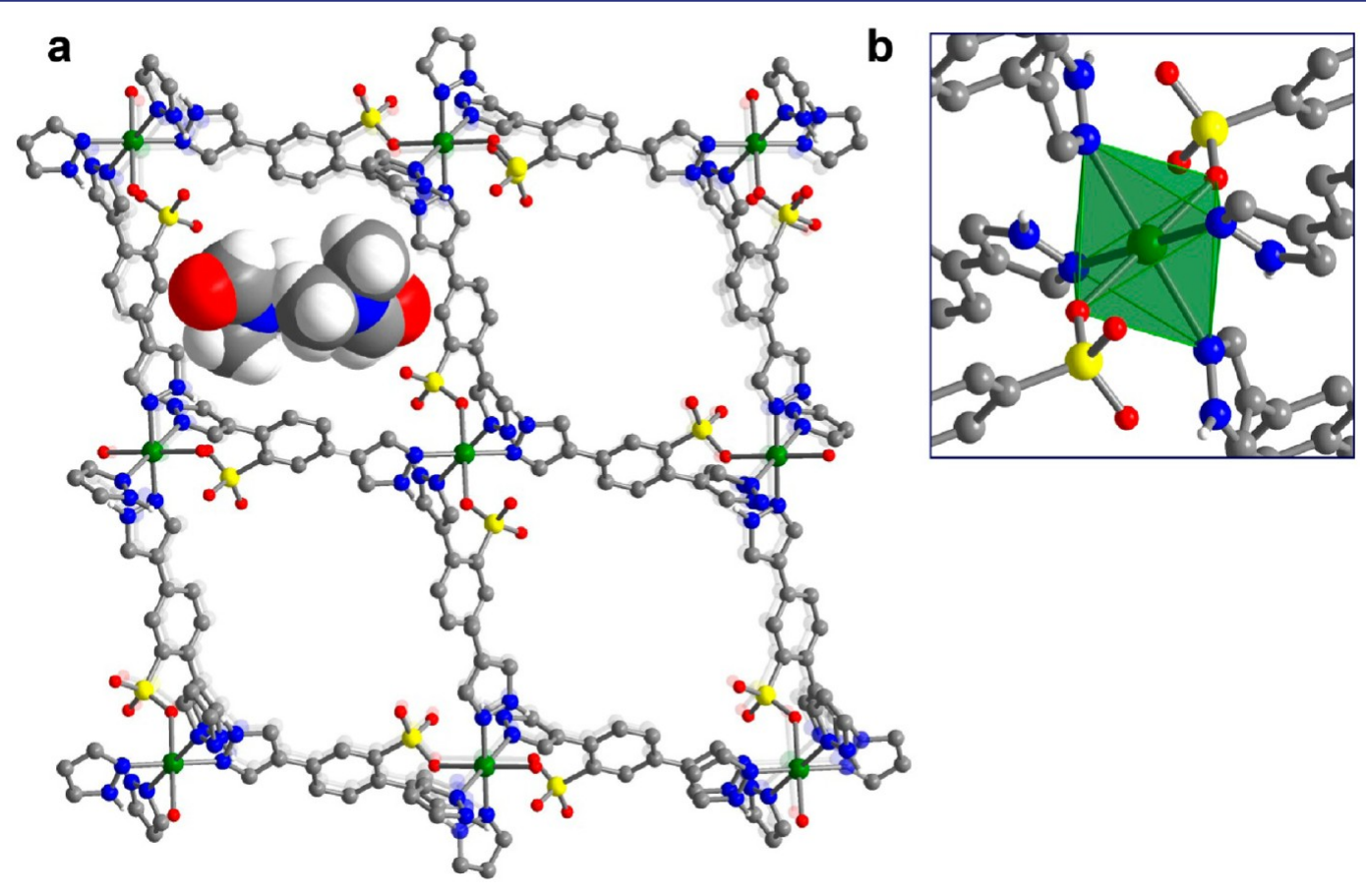

Figure 2. (a) Schematic drawing of the crystal structure of $\mathrm{Ni}\left(\mathrm{H}_{2} \mathrm{BDP} \_\mathrm{SO}_{3}\right)_{2} \cdot 2 \mathrm{DMF}$ viewed down $a$, with two DMF molecules highlighted in one of its cavities; and (b) magnification of the stereochemistry at the $\mathrm{Ni}(\mathrm{II})$ ions. 


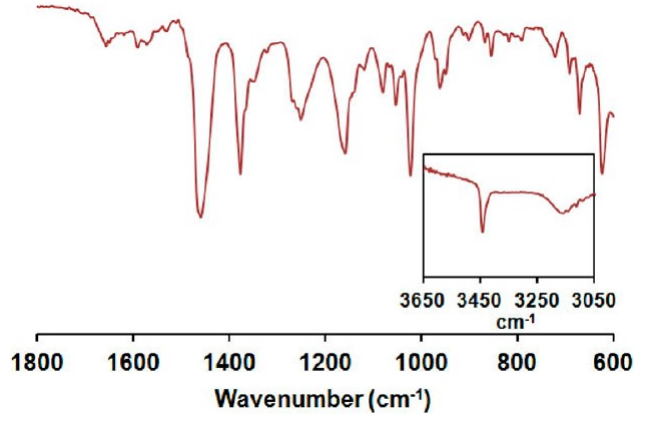

Figure 3. FTIR spectra of $\mathrm{NiBDP} \mathrm{SO}_{3} \mathrm{H}$ recorded as nujol mull. The inset highlights the IR region around $3500 \mathrm{~cm}^{-1}$ in which the two absorption bands of a desolvated material are visible.

converted into a hydroxo functionality, ${ }^{17}$ leading to 2hydroxo[1,4-bis(1H-pyrazol-4-yl)benzene], $\mathbf{H}_{2}$ BDP_OH. Finally, the electrophilic aromatic substitution for the preparation of benzene sulfonic acids was exploited to obtain the 2,5- $\mathrm{di}(1 \mathrm{H}$ pyrazol-4-yl)benzenesulfonic acid derivative, $\mathbf{H}_{2} \mathbf{B D P} \mathbf{S O}_{3} \mathbf{H}$.

Later, for the preparation of isostructural series of porous MOFs based on the $\mathbf{H}_{2}$ BDP $\mathbf{X}$ spacers, we focused our attention on nickel(II) and zinc(II) ions, which generally result in stable frameworks of easy handling in air, as properly witnessed, for example, by the NiBDP and ZnBDP archetypes. ${ }^{9 a}$ NiBDP was originally obtained by reacting the $\mathrm{H}_{2} \mathrm{BDP}$ ligand with $\mathrm{Ni}(\mathrm{II})$ acetate in acetonitrile at $80{ }^{\circ} \mathrm{C}$ in the presence of triethylamine. The isolated product was invariably contaminated by unreacted $\mathrm{H}_{2} \mathrm{BDP}$, which is extremely insoluble in the reaction solvent, implying the necessity of an additional washing procedure in dimethylsulfoxide at $60^{\circ} \mathrm{C}$. On the other hand, ZnBDP was isolated as a pure product, by reacting $\mathrm{Zn}\left(\mathrm{ClO}_{4}\right)_{2}$ with $\mathrm{H}_{2} \mathrm{BDP}$ in benzonitrile and triethylamine. ${ }^{18}$ Notably, in this work, the more suitable preparation found to afford the whole series of MBDP $\mathbf{X}\left(\mathrm{M}=\mathrm{Ni}^{2+}, \mathrm{Zn}^{2+}\right.$; $\left.\mathrm{X}=\mathrm{NO}_{2}, \mathrm{NH}_{2}, \mathrm{OH}\right)$ frameworks, in a polycrystalline and pure form, differs with respect to the original ones. Indeed, acetate salts were reacted with the organic linkers in boiling $N, N^{\prime}$ dimethylformamide, in the absence of extra base, such as triethylamine, in the reaction system. Interestingly, the very same procedure was proved to be viable also for the parent frameworks NiBDP and ZnBDP, providing polycrystalline and pure DMF solvates. Worthy of note, this synthetic procedure is reproducible and could be scaled up, making these MOFs available on a large scale.

Unfortunately, any attempt to produce a MOF containing the ligand bearing the sulfonic acid functionality $\left(\mathrm{H}_{2} \mathrm{BDP} \mathrm{SO}_{3} \mathrm{H}\right.$, see Scheme 1) and isostructural to the other MBDP_X materials invariably failed. However, by employing different synthetic conditions, a structural isomer of the parent NiBDP species was obtained (vide infra), in the following labeled as NiBDP_SO $\mathbf{S O}_{3} \mathrm{H}$. On the contrary, repeated attempts at obtaining a pure phase with $\mathrm{Zn}$ (II) ions, by varying the synthesis parameters, such as time, temperature program, stoichiometry, solvents, and $\mathrm{pH}$, were unsuccessful.

Crystal Chemistry. The bulk crystallinity and structural topology of each tagged MOF was evaluated by X-ray powder diffraction (XRPD). Their diffraction patterns are reported in Figure S2, revealing that all materials are crystalline, although no single crystals were ever formed. The comparison between the diffraction patterns of the parent materials and those of the tagged MOFs demonstrates the formation of pure, topologically equivalent, phases for both the NiBDP $\mathbf{X}$ and the ZnBDP_X $\left(\mathrm{X}=\mathrm{NO}_{2}, \mathrm{NH}_{2}, \mathrm{OH}\right)$ series. Thus, like NiBDP, the NiBDP_X compounds crystallize in the orthorhombic space group Imma and feature a porous framework in which the metal chains are arranged in a rhombic disposition, governed by the square-planar geometry of the $\mathrm{Ni}$ (II) ions. On the contrary, in ZnBDP and ZnBDP_X, linear chains of tetrahedrally
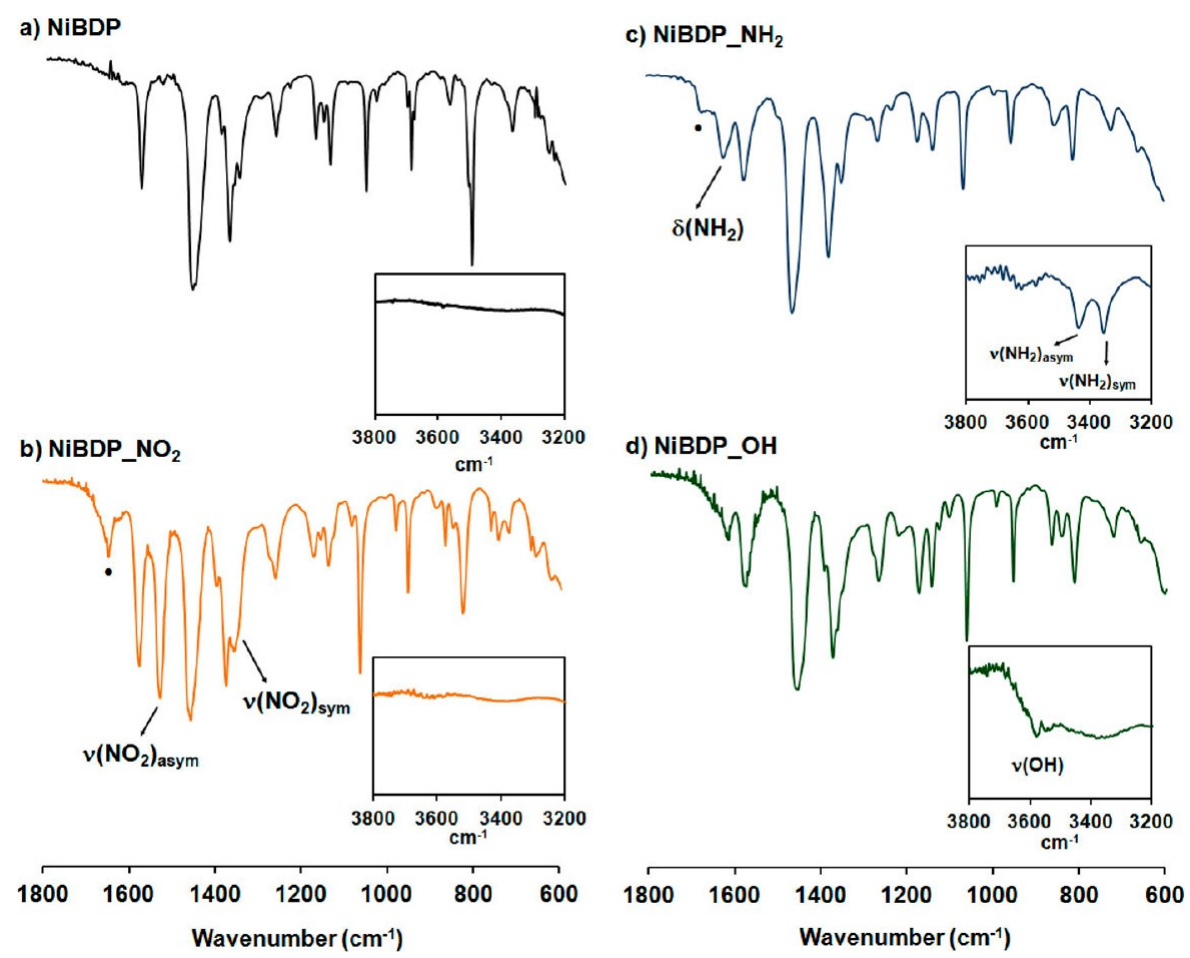

Figure 4. FTIR spectra of NiBDP_X $\left(\mathrm{X}=\mathrm{H}, \mathrm{NO}_{2}, \mathrm{NH}_{2}, \mathrm{OH}\right)$ recorded as nujol mull. The symbol “๑” denotes residual DMF. 



Figure 5. Simultaneous DSC (--) and TG (-) analyses for $\mathbf{N i B D P} \mathbf{N H}_{2}$ (blue), $\mathbf{N i B D P} \mathbf{N O}_{2}$ (orange), NiBDP_OH (green), and NiBDP_SO ${ }_{3} \mathrm{H}$ (red).

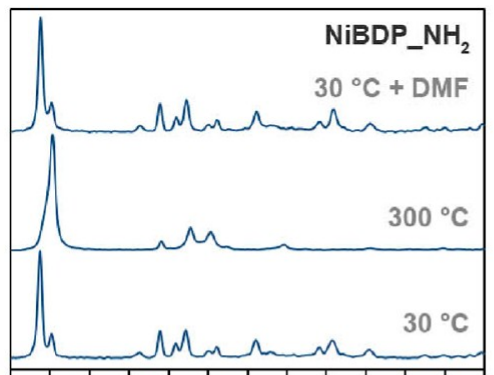

$6 \quad 8 \quad 10121416182022 \quad 242628 \quad 30$

$2 \theta$

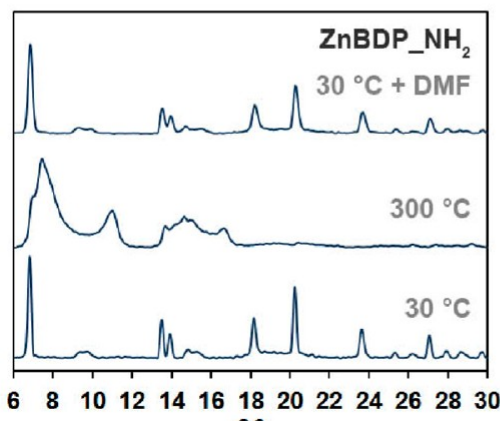

$2 \theta$

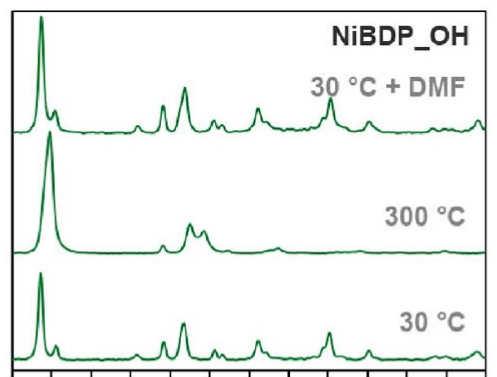

$\begin{array}{lllllllllllll}6 & 8 & 10 & 12 & 14 & 16 & 18 & 20 & 22 & 24 & 26 & 28 & 30\end{array}$ $2 \theta$

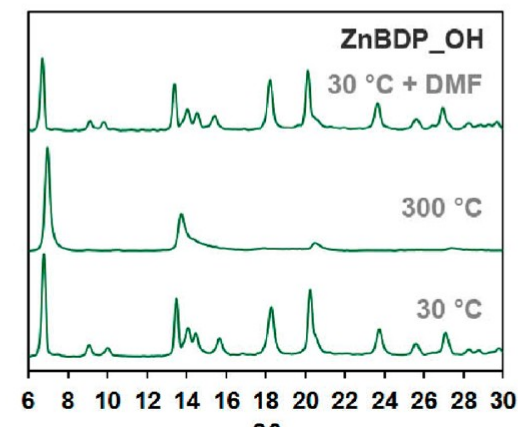

$2 \theta$
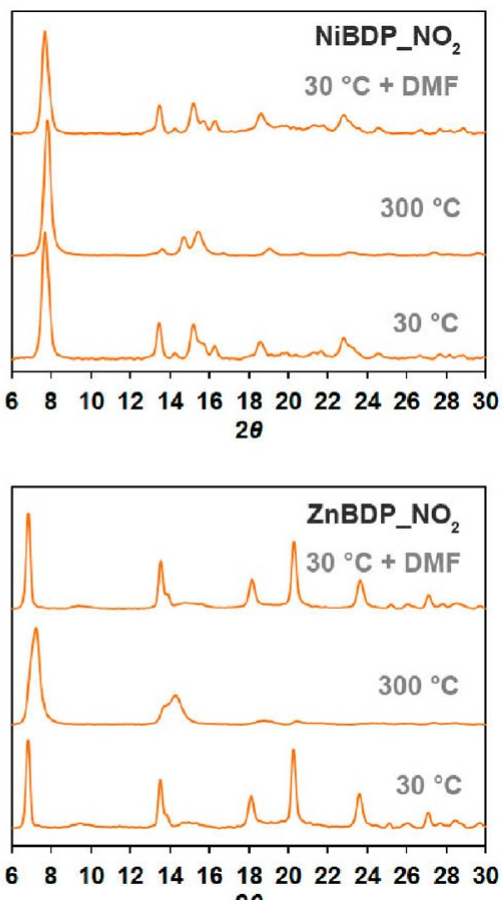

$2 \theta$

Figure 6. Powder X-ray diffraction patterns for each tagged $\mathrm{MBDP} \mathbf{X}$ framework $\left(\mathrm{M}=\mathrm{Ni}^{2+}, \mathrm{Zn}^{2+}, \mathrm{X}=\mathrm{NO}_{2}, \mathrm{NH}_{2}, \mathrm{OH}\right)$ collected, in the same experiment, at 30,300 , and back to $30{ }^{\circ} \mathrm{C}$ with further solvation with DMF.

coordinated $\mathrm{Zn}$ (II) ions are arranged to form a square lattice (see Figure 1). Unit cell parameters for each framework, derived by structureless Le Bail refinements, are reported in Table 1.

Regarding the ZnBDP_X series, as evidenced by independent indexing processes followed by Le Bail refinements, the new preparation carried out in DMF as the solvent leads to an orthorhombic deformation ( $C \mathrm{ccm}$ space group) of the parent tetragonal square-grid framework, possibly due to the actual nature and distribution of the solvent within the network pores (unit cell transformation from the tetragonal lattice requires that the $a+b$ and $a-b$ diagonals are taken as the new orthorhombic axes). This observation is not surprising, because lowering of the $\mathrm{Pt}_{2} / \mathrm{mmc}$ symmetry was also observed for the 

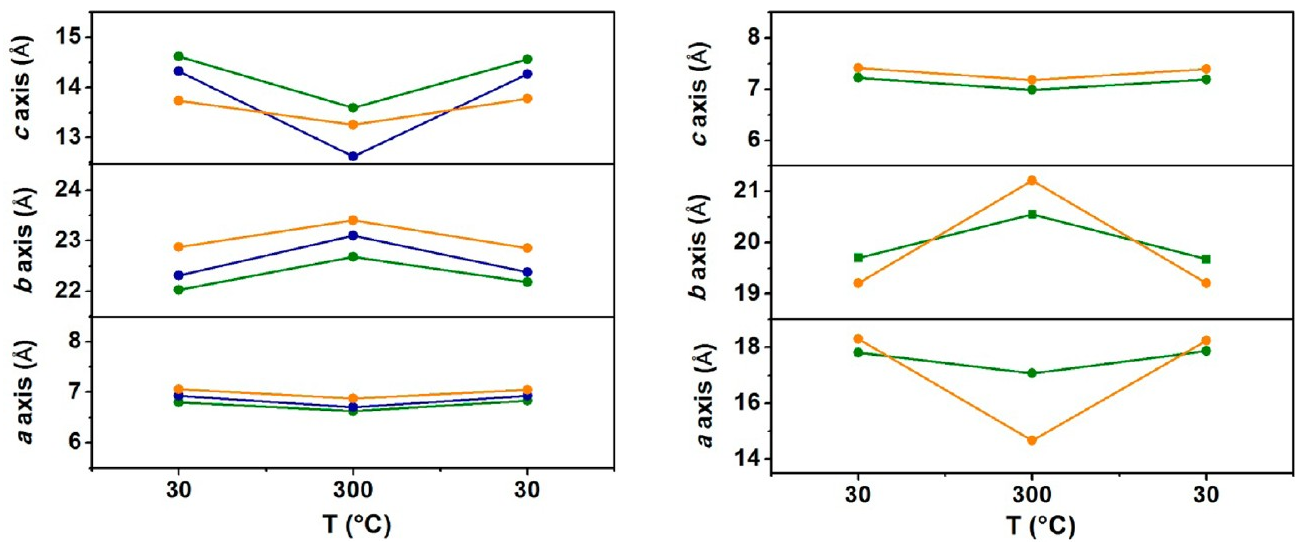

Figure 7. Variation of the unit cell axes upon thermally induced desolvation $\left(30-300{ }^{\circ} \mathrm{C}\right)$ and subsequent solvent readsorption $\left(\right.$ back to $30{ }^{\circ} \mathrm{C}$, see text). Left, NiBDP $\mathbf{X}$; right, ZnBDP $\mathbf{X}$. Orange, $\mathrm{NO}_{2}$; blue, $\mathrm{NH}_{2}$; green, $\mathrm{OH}$. Unit cell parameters for $\mathbf{Z n B D P} \mathbf{N H}_{2}$ are not available, due to its very low crystallinity at $300{ }^{\circ} \mathrm{C}$, preventing data treatment.



Figure 8. Variation of the unit cell parameters of NiBDP_SO $\mathrm{S}_{3} \mathrm{H} \cdot \mathrm{DMF}$ $\left(P_{\mathrm{T}}\right)$ normalized to the corresponding $90^{\circ} \mathrm{C}$ values $\left(P_{90}\right)$ as a function of the temperature, in the range $90-350{ }^{\circ} \mathrm{C}$. $a$, green; $b$, orange; $c$, blue; and $\beta$, red.

isostructural CoBDP derivative, isolated either as a $N, N^{\prime}$ diethylformamide solvate belonging to the orthorhombic space group $P 222_{1}^{23 a}$ or as a DMF solvate crystallizing in the monoclinic space group $P 2_{1} / c{ }^{19}$

In Figure S2, the powder diffraction pattern of the nickelbased framework bearing a sulfonic acid functionality on the benzene ring is reported. As is visually evident, its diffraction data differ from those of the other $\mathrm{Ni}(\mathrm{II})$ species. Structure solution from powder diffraction allowed one to disclose a new framework, of $\mathrm{Ni}\left(\mathrm{H}_{2} \mathrm{BDP} \mathrm{SO}_{3}\right)_{2} \cdot 2 \mathrm{DMF}$ formulation, which can be considered as an isomeric form of NiBDP. The local coordination geometry of this heteroleptic framework, in the following NiBDP_SO $\mathbf{S}_{3} \mathbf{H} \cdot \mathbf{2 D M F}$, can be appreciated in Figure $2 \mathrm{~b}$, while the overall structure is shown in Figure $2 \mathrm{a}$. This crystal phase is monoclinic, space group $P 2_{1} / c$; the asymmetric unit contains one crystallographically independent $\mathrm{Ni}$ (II) ion $\left(-1\right.$ position, Wyckoff site $a$ ) and one $\mathrm{H}_{2} \mathrm{BDP} \mathrm{SO}_{3}$ molecule (general position, Wyckoff site e). Each metal center is coordinated, in a trans- $\mathrm{NiN}_{4} \mathrm{O}_{2}$ octahedral stereochemistry, by four nitrogen atoms of four distinct ligand moieties and two oxygen atoms of the $-\mathrm{SO}_{3}$ groups of other two distinct ligands. The overall packing results in a $3 \mathrm{D}$ porous framework with monodimensional channels of almost square shape running parallel to $a$. The pore size generated by this arrangement is about $9 \times 7 \AA^{2}$ (van der Waals radii corrected) with two DMF molecules (per cell height) accommodated into the void volumes. Intriguingly, this new material preserves the flexible nature of NiBDP, as it displays a breathing of the framework related to the amount of solvent molecules located in its pores (see thermal behavior paragraph). Finally, it is worth noting that the ligand is deprotonated at the $-\mathrm{SO}_{3}$ functionality, thus featuring two crystallographically different $\mathrm{N}-\mathrm{H}$ groups: while one interacts through a hydrogen bond with an oxygen atom of the adjacent $-\mathrm{SO}_{3}$ moiety $(\mathrm{N}-\mathrm{H} \cdots \mathrm{O}=2.92 \AA)$, the second
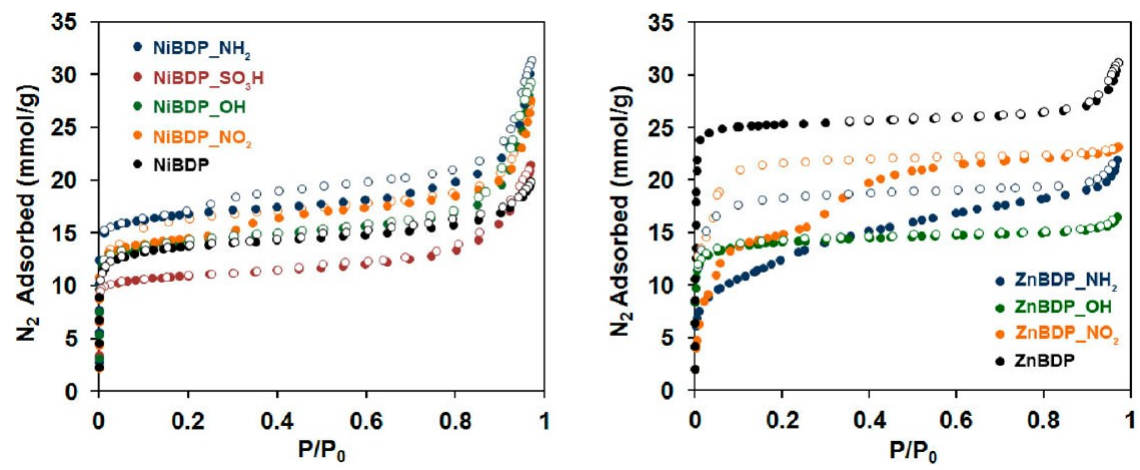

Figure 9. Left: $\mathrm{N}_{2}$ adsorption isotherms measured at $77 \mathrm{~K}$ for NiBDP_NH $\mathbf{N H}_{2}$ (blue), NiBDP_NO $\mathbf{N O}_{2}$ (orange), NiBDP_OH (green), NiBDP (black), and $\mathrm{NiBDP} \mathrm{SO}_{3} \mathrm{H}$ (red). Filled and empty symbols represent adsorption and desorption, respectively. Right: $\mathrm{N}_{2}$ adsorption isotherms measured at $77 \mathrm{~K}$ for ZnBDP_NH $\mathbf{N H}_{2}$ (blue), ZnBDP_NO $\mathbf{N}_{2}$ (orange), ZnBDP_OH (green), and ZnBDP (black). Filled and empty symbols represent adsorption and desorption, respectively. 

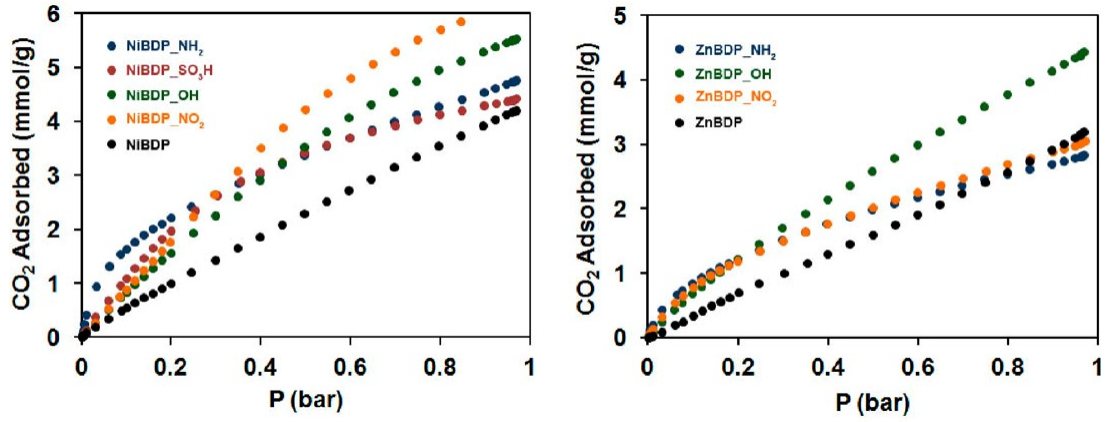

Figure 10. $\mathrm{CO}_{2}$ adsorption isotherms measured at $273 \mathrm{~K}$ for the $\mathrm{MBDP} \mathbf{X}\left(\mathrm{M}=\mathrm{Ni}, \mathrm{Zn}, \mathrm{X}=\mathrm{H}, \mathrm{NH}_{2}, \mathrm{NO}_{2}, \mathrm{OH}_{3} \mathrm{SO}_{3} \mathrm{H}\right)$ systems. $\mathbf{M B D P}_{-} \mathrm{NH}_{2}$ (blue), MBDP_NO 2 (orange), MBDP_OH (green), MBDP (black), and NiBDP_SO $\mathrm{H}_{3} \mathrm{H}$ (red).

Table 3. Isosteric Heats $\left(Q_{\mathrm{st}}\right)$, Henry Constants $\left(K_{\mathrm{H}}\right)$, and Adsorption Selectivities $(\alpha)$ of the NiBDP_X Systems Obtained from Pulse Gas Chromatographic Studies

\begin{tabular}{|c|c|c|c|c|c|c|}
\hline $\begin{array}{l}\text { adsorbate } \\
\text { (A) }\end{array}$ & $Q_{s t}\left(\mathrm{~kJ} \mathrm{~mol}^{-1}\right)$ & $K_{\mathrm{H}}\left(\mathrm{cm}^{3} \mathrm{~m}^{-2}\right)^{a}$ & $\begin{array}{c}\text { partition coefficient } \\
\alpha_{\mathrm{CH} 4 / \mathrm{A}}{ }^{a}\end{array}$ & $\begin{array}{c}\text { partition coefficient } \\
\alpha_{\mathrm{CO} 2 / \mathrm{A}}{ }^{\mathrm{C}}\end{array}$ & $\begin{array}{c}\text { partition coefficient } \\
\alpha_{\mathrm{C} 2 \mathrm{H} 2 / \mathrm{A}}{ }^{2}\end{array}$ & $\begin{array}{c}\text { partition coefficient } \\
\alpha_{\mathrm{H} 2 \mathrm{O} / \mathrm{A}}\end{array}$ \\
\hline \multicolumn{7}{|c|}{ NiBDP } \\
\hline $\mathrm{C}_{2} \mathrm{H}_{2}$ & $-25.05(2)$ & $0.098(6)$ & 0.072 & 0.74 & & 54 \\
\hline $\mathrm{CO}_{2}$ & $-20.02(9)$ & $0.052(3)$ & 0.097 & & 1.35 & 101 \\
\hline $\mathrm{CH}_{4}$ & & $0.005(1)$ & & 10 & 13.8 & 1000 \\
\hline $\mathrm{H}_{2} \mathrm{O}$ & $-42.5(6)$ & $5.30(2)$ & 0.001 & 0.01 & 0.02 & \\
\hline \multicolumn{7}{|c|}{ NiBDP_NH ${ }_{2}$} \\
\hline $\mathrm{C}_{2} \mathrm{H}_{2}$ & $-32.50(5)$ & $0.267(1)$ & 0.02 & 0.35 & & 38 \\
\hline $\mathrm{CO}_{2}$ & $-28.2(1)$ & $0.0894(4)$ & 0.056 & & 2.80 & 115 \\
\hline $\mathrm{CH}_{4}$ & & $0.005(1)$ & & 17.85 & 50 & 2052 \\
\hline $\mathrm{H}_{2} \mathrm{O}$ & $-51.3(2)$ & $10.3(7)$ & 0.0005 & 0.01 & 0.03 & \\
\hline \multicolumn{7}{|c|}{ NiBDP_NO $\mathrm{NO}_{2}$} \\
\hline $\mathrm{C}_{2} \mathrm{H}_{2}$ & $-23.3(2)$ & $0.0620(9)$ & 0.09 & 0.81 & & \\
\hline $\mathrm{CO}_{2}$ & $-25.1(3)$ & $0.12(1)$ & 0.12 & & 1.23 & \\
\hline $\mathrm{CH}_{4}$ & & $0.005(1)$ & & 8.13 & 10 & \\
\hline \multicolumn{7}{|c|}{ NiBDP_OH } \\
\hline $\mathrm{C}_{2} \mathrm{H}_{2}$ & $-26.10(5)$ & $0.19(1)$ & 0.26 & 0.77 & & \\
\hline $\mathrm{CO}_{2}$ & $-21.20(7)$ & $0.0680(2)$ & 0.33 & & 1.29 & \\
\hline $\mathrm{CH}_{4}$ & & $0.005(1)$ & & 3.60 & 4.66 & \\
\hline
\end{tabular}

one protrudes into the channels. This is further evidenced by means of IR spectroscopy where, in the region relevant for $\mathrm{N}-$ $\mathrm{H}$ stretching modes, two absorption bands, a sharp one at 3440 $\mathrm{cm}^{-1}$ and another one, of a broad shape, at $3150 \mathrm{~cm}^{-1}$, are found (Figure 3).

IR Spectroscopy Characterization. Because each functional group introduced on the organic linkers shows characteristic signals in the IR region, both series of MBDP_X were studied by means of IR spectroscopy. Figure 4 shows the comparison between the IR spectra of the parent NiBDP and the tagged nickel-based MOFs: in the spectra of the latter, typical absorption modes of the $\mathrm{NO}_{2}, \mathrm{NH}_{2}, \mathrm{OH}$, and $\mathrm{SO}_{3}{ }^{-}$functional groups are found, further confirming the effective functionalization of the pore surfaces of each MOF. The Supporting Information provides a complete description of the IR spectroscopy characterization.

Thermal Behavior. Simultaneous thermogravimetric and differential scanning calorimetry analyses (STA) performed on the two series of nickel(II) and zinc(II) materials demonstrated the high thermal stability of their pyrazolate-bridged frameworks, even in the presence of substituents on the organic linkers (see Figures 5 and S5).

Lillerud et al. reported ${ }^{5 \mathrm{~g}}$ the difficulty in finding a simple correlation between the thermal stability of tagged UiO-66
MOFs and both the electronic and steric nature of the functional groups introduced on the organic linkers. However, here, by considering the electronic effects of each functional group, a simple correlation between thermal stability and Hammett $\sigma$ values of the substituents can be envisaged. ${ }^{20}$ Indeed, the $\mathrm{NH}_{2}$-tagged ligand is electron rich and the $\mathrm{NO}_{2}$ tagged one is electron poor, while the $-\mathrm{H},-\mathrm{OH}$, and $-\mathrm{SO}_{3} \mathrm{H}^{21}$ substituents have Hammett $\sigma$ values somewhere between. For the $\mathrm{Ni}(\mathrm{II})$ series, there is a good correlation between the tabulated Hammett $\sigma$ values and the decomposition temperatures obtained by STA, the highest thermal stability being observed for the amino-tagged MOF $\left(T_{\mathrm{d}}\right.$ ca. 470 $\left.{ }^{\circ} \mathrm{C}\right)$. Decomposition temperatures nicely follow the trend $\mathrm{NO}_{2}$ $<\mathrm{SO}_{3} \mathrm{H}<\mathrm{OH}<\mathrm{H}<\mathrm{NH}_{2}\left(400<T_{\mathrm{d}}<470{ }^{\circ} \mathrm{C}\right)$. However, this is not true for the $\mathbf{Z n B D P} \mathbf{X}$ series, along which all samples (but the amino one, with $T_{\mathrm{d}}$ ca. $470{ }^{\circ} \mathrm{C}$ ) undergo decomposition at rather similar temperatures $\left(T_{\mathrm{d}}\right.$ ca. $420{ }^{\circ} \mathrm{C}$, in line with that previously observed for ZnBDP). ${ }^{9 a}$

In the TG curves of the as-synthesized forms of all of the MBDP X materials (Figures 5 and S5 for NiBDP $\mathbf{X}$ and ZnBDP_X, respectively), each weight loss step that occurs below the decomposition temperature can be assigned to the removal of the occluded guest molecules. Worthy of note, in the DSC curves the thermal events due to solvent loss and 
Table 4. Isosteric Heats $\left(Q_{\mathrm{st}}\right)$, Henry Constants $\left(K_{\mathrm{H}}\right)$, and Adsorption Selectivities $(\alpha)$ of the ZnBDP_X Systems Obtained from Pulse Gas Chromatographic Studies

\begin{tabular}{|c|c|c|c|c|c|c|}
\hline $\begin{array}{l}\text { adsorbate } \\
\text { (A) }\end{array}$ & $Q_{s t}\left(\mathrm{~kJ} \mathrm{~mol}^{-1}\right)$ & $K_{\mathrm{H}}\left(\mathrm{cm}^{3} \mathrm{~m}^{-2}\right)^{a}$ & $\begin{array}{l}\text { partition coefficient } \\
\alpha_{\mathrm{CH} 4 / \mathrm{A}}{ }^{2}\end{array}$ & $\begin{array}{c}\text { partition coefficient } \\
\alpha_{\mathrm{CO} 2 / \mathrm{A}}{ }^{a}\end{array}$ & $\begin{array}{l}\text { partition coefficient } \\
\qquad \alpha_{\mathrm{C} 2 \mathrm{H} 2 / \mathrm{A}}\end{array}$ & $\begin{array}{c}\text { partition coefficient } \\
\alpha_{\mathrm{H} 2 \mathrm{O} / \mathrm{A}}{ }^{a}\end{array}$ \\
\hline \multicolumn{7}{|c|}{ ZnBDP } \\
\hline $\mathrm{C}_{2} \mathrm{H}_{2}$ & $-20.2(2)$ & $0.015(6)$ & 0.85 & 1.02 & & 137 \\
\hline $\mathrm{CO}_{2}$ & $-19.7(2)$ & $0.0093(7)$ & 0.84 & & 0.98 & 228 \\
\hline $\mathrm{CH}_{4}$ & & $0.005(1)$ & & 2.39 & 2.35 & 412 \\
\hline $\mathrm{H}_{2} \mathrm{O}$ & $-46.7(3)$ & $2.1(9)$ & 0.0025 & 0.004 & 0.007 & \\
\hline \multicolumn{7}{|c|}{$\mathrm{ZnBDP} \mathrm{NO}_{2}$} \\
\hline $\mathrm{C}_{2} \mathrm{H}_{2}$ & $-23.51(9)$ & $0.042(3)$ & 0.11 & 0.89 & & 49 \\
\hline $\mathrm{CO}_{2}$ & $-21.4(1)$ & $0.022(4)$ & 0.13 & & 1.13 & 93 \\
\hline $\mathrm{CH}_{4}$ & & $0.005(1)$ & & 16.6 & 18.7 & 401 \\
\hline $\mathrm{H}_{2} \mathrm{O}$ & $-42.8(6)$ & $2.0(6)$ & 0.0025 & 0.011 & 0.021 & \\
\hline \multicolumn{7}{|c|}{ ZnBDP_NH ${ }_{2}$} \\
\hline $\mathrm{C}_{2} \mathrm{H}_{2}$ & $-31.82(4)$ & $0.16(1)$ & 0.31 & 0.90 & & 59 \\
\hline $\mathrm{CO}_{2}$ & $-28.1(1)$ & $0.083(3)$ & 0.35 & & 1.11 & 113 \\
\hline $\mathrm{CH}_{4}$ & & $0.005(1)$ & & 5.74 & 6.39 & 2000 \\
\hline $\mathrm{H}_{2} \mathrm{O}$ & $-51.2(6)$ & $9.4(2)$ & 0.0005 & 0.009 & 0.017 & \\
\hline \multicolumn{7}{|c|}{ ZnBDP_OH } \\
\hline $\mathrm{C}_{2} \mathrm{H}_{2}$ & $-29.11(8)$ & $0.073(3)$ & 0.18 & 0.34 & & \\
\hline $\mathrm{CO}_{2}$ & $-22.9(2)$ & $0.026(8)$ & 0.54 & & 2.9 & \\
\hline $\mathrm{CH}_{4}$ & & $0.005(1)$ & & 12.1 & 35.7 & \\
\hline
\end{tabular}
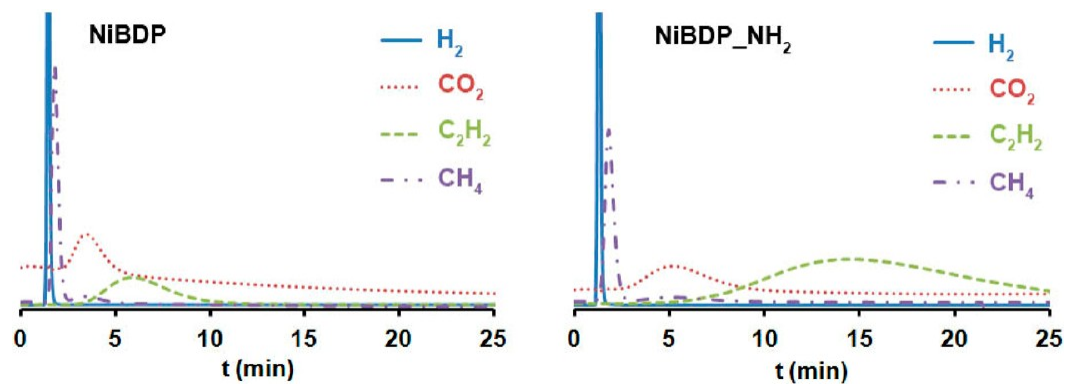

Figure 11. Pulse gas chromatograms for an equimolecular mixture of $\mathrm{C}_{2} \mathrm{H}_{2}, \mathrm{H}_{2}, \mathrm{CH}_{4}$, and $\mathrm{CO}_{2}$, collected at $273 \mathrm{~K}$. For the sake of simplicity, the curves are reported only for NiBDP and NiBDP_ $\mathbf{N H}_{2}$. Chromatograms for other tagged frameworks are reported in the Supporting Information.

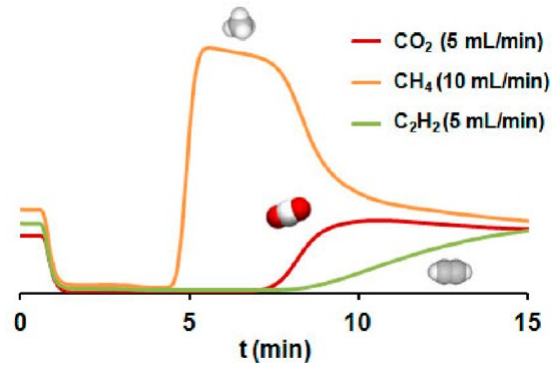

Figure 12. $\mathrm{CH}_{4} / \mathrm{CO}_{2} / \mathrm{C}_{2} \mathrm{H}_{2}$ separation breakthrough experiments performed on NiBDP at $273 \mathrm{~K}$.

material decomposition ${ }^{22}$ are well separated (by ca. $200{ }^{\circ} \mathrm{C}$ ), further confirming the high stability of these frameworks (see the Supporting Information).

Variable-temperature X-ray powder diffraction experiments were also performed to assess the thermal and structural stability of these metal-organic frameworks. In a typical experiment, carried out in air, three diffractograms for each sample were collected at (i) $30{ }^{\circ} \mathrm{C}$, on the solvated material, (ii) $300^{\circ} \mathrm{C}$, and (iii) back to $30^{\circ} \mathrm{C}$, with further addition of solvent ( $N, N^{\prime}$-dimethylformamide, DMF) to the sample. As reported in Figure 6, while preserving the unit cell symmetry, the
Table 5. Amount of $\mathrm{CO}_{2}\left(\mathrm{mmol} \mathrm{g}^{-1}\right)$ Retained in Dynamic Conditions As Retrieved from $\mathrm{CO}_{2} / \mathrm{N}_{2}$ Breakthrough Experiments at Different Temperatures for the MBDP $\mathrm{X}$ Systems

\begin{tabular}{|cccc} 
MOF & $273 \mathrm{~K}$ & $298 \mathrm{~K}$ & $323 \mathrm{~K}$ \\
\hline ZnBDP & 0.34 & & \\
ZnBDP_NO $_{2}$ & 0.63 & 0.27 & 0.16 \\
ZnBDP_NH & 1.02 & 0.57 & 0.28 \\
ZnBDP_OH & 0.50 & 0.20 & 0.15 \\
NiBDP & 0.69 & $0.32^{a}$ & 0.17 \\
NiBDP_NO & 1.07 & 0.38 & 0.24 \\
NiBDP_NH & 1.34 & 0.54 & 0.32 \\
NiBDP_OH & 0.89 & $0.35^{a}$ & 0.23 \\
NiBDP_SO & 1.04 & & \\
${ }^{a}$ Calculated at 303 K. & & &
\end{tabular}

desolvation process brings about definite changes in the positions and intensities of the XRPD peaks. In the NiBDP_X series, as was already observed for NiBPD, ${ }^{9 a}$ the $a$ axis, which corresponds to the metal chains propagation direction, is the least affected by the thermal treatment. On the contrary, $b$ and $c$ undergo higher and inversely correlated variations that well witness the flexible nature of this $3 \mathrm{D}$ framework. Indeed, the 



Figure 13. $\mathrm{N}_{2} / \mathrm{CO}_{2}$ separation breakthrough experiments at $273 \mathrm{~K}$, showing the effect of tag nature within the ZnBDP_X series. Breakthrough curves for other tagged frameworks are reported in the Supporting Information.

rhombic channels deflate with increasing temperature and release of solvent, leading to progressively smaller unit cell volumes (Figure 7 and Table 1).

In our previous study, ${ }^{9 a}$ the parent ZnBDP framework was found to be rather stiff when heated in the diffractometer cradle. This rigid behavior was attributed to the stereochemical rigidity of the $\mathrm{ZnN}_{4}$ tetrahedron and of its polyconnected tetragonal lattice. Here, however, the tagged ZnBDP_X series shows a higher degree of flexibility promoted by solvent release (Figure 6). This is particularly evident for $\mathbf{Z n B D P} \mathbf{N H}_{2}$, whose HT phase cannot be easily traced back to the solvated one due to profound changes in the structure. On the contrary, the HT phases of the $\mathrm{NO}_{2}$ - and $\mathrm{OH}$-tagged MOFs can still be related to their solvated counterparts with smaller unit cell volumes (Table 1). Surprisingly, even for ZnBDP_ $\mathbf{N H}_{2}$, after exposure of the HT phases to DMF, the original diffraction patterns are regenerated, as a further confirmation of the high stability and flexible nature of our tagged pyrazolate-based MOFs. For both series, these observations are consistent with an accordion-type flexing behavior that closes and opens the channel pores as a function of the external stimulus, as previously observed, for example, not only for NiBDP, ${ }^{9 a}$ but also for Long's CoBDP, ${ }^{23}$ Feréy's MIL-53 and MIL-88 families, ${ }^{5 f}$ and Yaghi's ZIF-7. ${ }^{24}$

Another surprising behavior was detected on the NiBD$\mathrm{P} \mathbf{S O}_{3} \mathrm{H}$ material with a thermodiffractometric experiment. Diffraction data were collected on the DMF-solvated NiBDP_SO $\mathrm{S}_{3} \mathrm{H} \cdot 2 \mathrm{DMF}$ in the range $30-350{ }^{\circ} \mathrm{C}$ with steps of $20{ }^{\circ} \mathrm{C}$. By raising the temperature to $90{ }^{\circ} \mathrm{C}$, NiBDP SO $_{3} \mathbf{H} \cdot 2 \mathrm{DMF}$ loses solvent with a fast kinetics (less than $30 \mathrm{~min})$ leading to another metastable solvate, NiBDP_SO 3 H・DMF, with a lower solvent content. Structure solution on data collected at this temperature shows that, while the overall stereochemistry of the $\mathrm{Ni}(\mathrm{II})$ ions remains intact, the lower solvent content induces a deformation of the channels to a rhombic shape, with a concomitant unit cell volume shrinking of about $9 \%$. Indeed, in this crystal structure, only one DMF molecule (per cell height) is present in each cavity, disordered on two, crystallographically equivalent, sites. Further heating of NiBDP $\mathrm{SO}_{3} \mathrm{H} \cdot \mathrm{DMF}$ produces further cell parameter changes in the same direction as those described above for the NiBDP compound, with limited cell volume variation. The results of a structureless Le Bail refinement of the TXRPD data in the range $90-350{ }^{\circ} \mathrm{C}$ are reported in Figure 8. Again, $a$ is only marginally affected, while $b$ and $c$ show significant and inversely correlated variations. Moreover, at $250{ }^{\circ} \mathrm{C}$, a structure solution process revealed that the framework maintains the same stereochemistry at the $\mathrm{Ni}$ (II) ions, with empty rhombic voids of about $6 \times 8 \AA^{2}$ (van der Waals radii corrected).
Adsorption Properties. One of the areas of highest interest in the field of MOFs research is the potential application of their selective adsorption properties for gas separation and purification purposes. ${ }^{25}$ Particularly, the possible application of these systems in greenhouse gas capture processes is one of the most challenging research areas. ${ }^{26}$ To examine the suitability of the MBDP $\mathbf{X}$ species for this application, we carried out different studies for characterizing their porous nature, conventional single component adsorption isotherms, as well as advanced experiments (pulse gas chromatography and breakthrough curve measurements).

Static Adsorption Experiments. To evaluate the permanent porosity of the MBDP $\mathbf{X}$ materials, $\mathrm{N}_{2}$ adsorption/desorption isotherms at $77 \overline{\mathrm{K}}$ (see Figure 9) were collected, and Langmuir specific surface areas were consequently calculated (Table 2). $\mathrm{CO}_{2}$ isotherms at $273 \mathrm{~K}$ (Figure 10) were used to evaluate the micropore region by means of the Dubinin-Radushkevich equation (Table 2). All of the tagged MOFs were found to retain porosity to both $\mathrm{N}_{2}$ and $\mathrm{CO}_{2}$ despite the presence of different functional groups on the linker.

The Langmuir specific surface areas were found to range between 1044 and $1645 \mathrm{~m}^{2} / \mathrm{g}$ and 1484 and $2860 \mathrm{~m}^{2} / \mathrm{g}$ for NiBDP_X and ZnBDP_X, respectively. Moreover, they follow different trends within the two series, NiBDP_ $\mathbf{N H}_{2}>$ $\mathrm{NiBDP} \mathrm{NO}_{2}>\mathrm{NiBDP} \mathrm{OH}>\mathrm{NiBDP}>\mathrm{NiBDP} \mathrm{SO}_{3} \mathrm{H}$ for the nickel(II) materials, and $\mathrm{ZnBDP}>\mathrm{ZnBDP} \mathrm{NO}_{2}>$ ZnBDP_NH $\mathbf{N H}_{2}>$ ZnBDP_OH along the zinc(II) series. The decrease in surface areas for the zinc(II) tagged frameworks, as compared to the parent ZnBDP structure, follows the $V / Z$ trend and can be largely attributed to both the reduced free space available and an overall increased weight of the MOFs as a result of introducing substituents on the organic linker. Within the tagged materials, ZnBDP_NO $\mathbf{N O}_{2}$ shows the highest surface area, concomitant to the presence of a hysteretic loop. This feature is observed also in the isotherm of the aminotagged MOF, although to a lesser extent. By contrast, ZnBDP_OH shows the lowest $\mathrm{N}_{2}$ uptake, with a classical type I isotherm. For flexible-type MOFs with hydroxyl groups decorating the pores walls, the formation of intraframework interactions can be envisaged to explain the low uptake. ${ }^{\text {5e }}$ The occurrence of hysteresis loops along the $\mathrm{N}_{2}$ isotherm has been previously observed in Long's CoBDP. ${ }^{22}$ As was already pointed out, ZnBDP $\mathbf{X}$ and CoBDP are isostructural, and, consequently, a similar flexible behavior can be expected. Noteworthy, as was already pointed out in the thermal behavior paragraph, although ZnBDP behaved only as a rigid framework, ${ }^{9 a}$ the introduction of tags is responsible for an increased flexibility. 
$\mathrm{CO}_{2}$ isotherms at $273 \mathrm{~K}$ were also collected to investigate the adsorption properties of each tagged framework with respect to this gas of environmental significance. ${ }^{27}$ Indeed, the results show that the introduction of tags on the BDP linkers gives rise to a general increase of the steep of the adsorption isotherm in the low pressure region, which can be attributed to a narrowing of the pore size with a concomitant increase of the adsorbateadsorbent interactions. This fact is particularly evident in the case of the $-\mathrm{NH}_{2}$ substituents, in the presence of which the formation of $\mathrm{H}$-bonding interactions with the quadrupolar $\mathrm{CO}_{2}$ molecules should be claimed to explain the enhancement of the adsorption energy. ${ }^{28}$ These results are further confirmed on the basis of variable-temperature pulse gas experiments (see below).

Pulse Gas Chromatographic Studies. To assess the possible application of these materials on gas purification processes, a chromatographic column was constructed and packed with each tagged MOF. The samples were first pelletized to avoid pressure drops over the column. Afterward, the adsorption selectivity of the materials was studied by injecting a complex gas mixture $(1 \mathrm{~mL})$, composed of equimolecular amounts of $\mathrm{C}_{2} \mathrm{H}_{2}, \mathrm{H}_{2}, \mathrm{CH}_{4}$, and $\mathrm{CO}_{2}$, on an

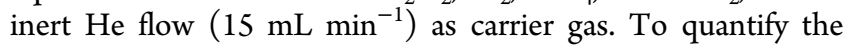
strength of the interaction of these guest molecules with the tagged materials, their zero-coverage adsorption heats $\left(\Delta H_{\text {ads }}\right)$ were derived from the variation of the retention volumes $\left(V_{\mathrm{g}}\right)$ as a function of temperature, according to the ClausiusClapeyron type equation $\Delta H_{\mathrm{ads}}=-R \delta\left(\ln V_{\mathrm{g}}\right) / \delta(1 / T) .{ }^{29}$ The direct relation between the retention volume $\left(V_{\mathrm{g}}\right)$ and Henry constant $\left(K_{\mathrm{H}}\right)$ also permits one to calculate the Henry constant values at $298 \mathrm{~K}$ (Tables 3 and 4). The results for the NiBDP_X series show that the retention volumes follow the trend $\mathrm{H}_{2} \mathrm{O} \gg$ $\mathrm{C}_{2} \mathrm{H}_{2}>\mathrm{CO}_{2} \gg \mathrm{CH}_{4}>\mathrm{H}_{2}$ (see Figure 11; water is not shown because it has been measured separately). The interaction of $\mathrm{H}_{2}$ with the frameworks is almost negligible, and, consequently, it has been taken as reference value for the column dead volume.

Noteworthy, the introduction of polar tags in the framework is responsible for an enhancement of the interaction with polar adsorbates (higher adsorption energies), and a concomitant increase in the partition coefficients between apolar $\left(\mathrm{CH}_{4}\right)$ and polar $\left(\mathrm{CO}_{2}, \mathrm{C}_{2} \mathrm{H}_{2}\right)$ adsorbates (Tables 3 and 4$)$. However, the adsorption selectivity (partition coefficients) between $\mathrm{CO}_{2} /$ $\mathrm{C}_{2} \mathrm{H}_{2}$ is not significantly increased upon functionalization, which should be attributed to the closely related nature of these two types of adsorbates (possessing quadrupole moments, similar size, and similar physical properties). From these results, it can be concluded that the tagged materials are adequate for gas purification purposes, particularly for the removal of small impurities of polar gases and polar vapors (e.g., moisture, $\mathrm{CO}_{2}$, $\mathrm{C}_{2} \mathrm{H}_{2}$ ) from natural gas.

Gas Separation Breakthrough Experiments. In the case of bulk separation of gases, breakthrough experiments are the adequate experiments to assess the gas separation performances of a material. Thus, gas mixture adsorption breakthrough experiments were performed on columns packed with each tagged MOF. As for the above-described experiments, the samples were first pelletized to avoid pressure drops over the column, and the desired gas mixture was flowed through the material.

On the nonfunctionalized NiBDP system, a preliminary breakthrough experiment with a complex gas mixture of $\mathrm{CH}_{4}$, $\mathrm{CO}_{2}$, and $\mathrm{C}_{2} \mathrm{H}_{2}$ was performed to assess, qualitatively, the interaction of the framework with these gases. As expected, the results show that $\mathrm{CH}_{4}$ is not retained in the column in the essayed temperature range $(273-323 \mathrm{~K})$. The highest interactions of the material take place with the quadrupolar $\mathrm{CO}_{2}$ and $\mathrm{C}_{2} \mathrm{H}_{2}$ gases, which are efficiently retained in the essayed experimental conditions (Figure 12). For both gases, the interaction is similarly strong, and, consequently, in $\mathrm{CH}_{4}$ / $\mathrm{CO}_{2} / \mathrm{C}_{2} \mathrm{H}_{2}$ mixtures, both $\mathrm{CO}_{2}$ and $\mathrm{C}_{2} \mathrm{H}_{2}$ are jointly retained, although there is a higher retention of the latter.

Later, a much simpler experiment was carried out on the whole series of tagged MBDP $\mathbf{X}$ to simulate an emission flue gas from a power plant employing $1.4 \mathrm{~mL} \mathrm{~min}^{-1}$ of $\mathrm{CO}_{2}$ and $8.6 \mathrm{~mL} \mathrm{~min}^{-1}$ of $\mathrm{N}_{2}$ flows. ${ }^{30}$ Indeed, the breakthrough experiments were carried out by step changes from $\mathrm{He}$ to $\mathrm{CO}_{2} / \mathrm{N}_{2}$ flow mixtures. Again, the results show that $\mathrm{N}_{2}$ is not retained in the column, while, in the essayed temperature range $(273-323 \mathrm{~K})$, a high interaction takes with $\mathrm{CO}_{2}$. Framework functionalization plays an important role also in this separation; as a matter of fact, according to the low pressure region of the $\mathrm{CO}_{2}$ adsorption isotherms collected at $273 \mathrm{~K}$, the highest interaction was achieved for the MBDP $\mathbf{N H}_{2}$ systems (see Table 5 and Figure 13). Noteworthy, the quantities of $\mathrm{CO}_{2}$ retained at $323 \mathrm{~K}$, which is the typical condition of flue gas emission from a fossil fuel power plant, are 0.28 and $0.32 \mathrm{mmol}$ $\mathrm{g}^{-1}$ for ZnBDP_ $\mathbf{N H}_{2}$ and NiBDP_ $\mathbf{N H}_{2}$, respectively.

\section{CONCLUSIONS}

The foregoing results confirm that pyrazolate-based ligands can successfully respond to the challenge of constructing isoreticular families of MOFs bearing organic functionalities, as a mean to tune pore size, shape, and volume, hence the adsorption capacity and selectivity toward specific guests. Specifically, we exploited the versatility of the $\mathrm{H}_{2} \mathrm{BDP}$ ligand for the straightforward introduction, on its benzene moiety, of different tags $\left(-\mathrm{NO}_{2},-\mathrm{NH}_{2},-\mathrm{OH},-\mathrm{SO}_{3} \mathrm{H}\right)$. By applying the appropriate reaction conditions, the tagged $\mathrm{H}_{2} \mathrm{BDP}$ X spacers were successfully employed in the isolation, on the gram scale, of the two series of NiBDP $\mathbf{X}$ and ZnMBDP_X materials. To the best of our knowledge, they represent the first families of robust, isoreticular pyrazolate-based MOFs with tagged ligands whose thermal behavior and adsorption properties have been systematically studied.

XRPD experiments, in isothermal conditions or varying the temperature, demonstrated the flexibility of their frameworks, existing in open- or closed-pore forms in response to stimuli such as solvent content or temperature modification. Despite the thermally induced flexibility of their frameworks, all of the materials not only maintain their functionality, but also exhibit a remarkable thermal stability, decomposing, in air, only at 400 ${ }^{\circ} \mathrm{C}$ or higher temperatures. Conventional single component adsorption isotherms and advanced experiments of pulse gas chromatography and breakthrough curve measurements allowed one to rationalize the effect of linker functionalization on the adsorption selectivity and capacity toward gases of environmental interest. Noteworthy, the adsorption selectivities (partition coefficients) for the resolution of mixtures of apolar and polar gases are highly improved (i.e., $\mathrm{N}_{2} / \mathrm{CO}_{2}$ or $\mathrm{CH}_{4} / \mathrm{CO}_{2}$ mixtures) with the introduction of polar tags. Nevertheless, this strategy fails in the improvement of the separation of polar gas mixtures (e.g., $\mathrm{CO}_{2} / \mathrm{C}_{2} \mathrm{H}_{2}$ ): in this case, the adsorption selectivity is not significantly increased upon functionalization, which should be attributed to the closely related nature of these two adsorbates (in terms of quadrupole moments, size, and physical properties). The reported results collectively evidence 
that our tagged materials are adequate for gas purification purposes, particularly for the removal of small impurities of polar gases and polar vapors (e.g., moisture, $\mathrm{CO}_{2}, \mathrm{C}_{2} \mathrm{H}_{2}$ ) from low polar ones (e.g., $\mathrm{N}_{2}, \mathrm{CH}_{4}, \mathrm{H}_{2}$ ).

\section{ASSOCIATED CONTENT}

\section{S Supporting Information}

Additional figures and experimental details, as well as CIF files. This material is available free of charge via the Internet at http://pubs.acs.org.

\section{AUTHOR INFORMATION}

\section{Corresponding Author}

valentina.colombo@uninsubria.it; jarn@ugr.es

\section{Notes}

The authors declare no competing financial interest.

\section{ACKNOWLEDGMENTS}

V.C. gratefully acknowledges the Regione Lombardia (Progetto DOTE, COMIX Challenges in OrganoMetallic Investigations by X-rays) for partial funding. The Spanish MCINN (CTQ2011-22787/PPQ) is gratefully acknowledged for generous funding.

\section{REFERENCES}

(1) (a) Themed issue on metal-organic frameworks: Chem. Rev. 2012, 112, 673-1268. (b) Kitagawa, S.; Kitaura, R.; Noro, S.-I. Angew. Chem., Int. Ed. 2004, 43, 2334. (c) Hamon, L.; Llewellyn, P. L.; Devic, T.; Ghoufi, A.; Clet, G.; Guillerm, V.; Pirngruber, G. D.; Maurin, G.; Serre, C.; Driver, G.; van Beek, W.; Jolimaitre, E.; Vimont, A.; Daturi, M.; Férey, G. J. Am. Chem. Soc. 2009, 131, 17490. (d) Taylor-Pashow, K. M. L.; Della Rocca, J.; Xie, Z. G.; Tran, S.; Lin, W. B. J. Am. Chem. Soc. 2009, 131, 14261. (e) Horcajada, P.; Chalati, T.; Serre, C.; Gillet, B.; Sebrie, C.; Baati, T.; Eubank, J. F.; Heurtaux, D.; Clayette, P.; Kreuz, C.; Chang, J. S.; Hwang, Y. K.; Marsaud, V.; Bories, Y.-N.; Cynober, L.; Gil, S.; Férey, G.; Couvreur, P.; Gref, R. Nat. Mater. 2010, 9, 172. (f) Liu, Y.; Kravtsov, V. C.; Larsen, R.; Eddaoudi, M. Chem. Commun. 2006, 1488. (g) Wiers, B. M.; Foo, M.-L.; Balsara, N. P.; Long, J. R. J. Am. Chem. Soc. 2011, 133, 14522. (h) Bloch, E. D.; Murray, L. M.; Queen, W. L.; Chavan, S.; Maximoff, S. N.; Bigi, J. P.; Krishna, R.; Peterson, V. K.; Grandjean, F.; Long, G. J.; Smit, B.; Bordiga, S.; Brown, C. M.; Long, J. R. J. Am. Chem. Soc. 2011, 133, 14814. (i) Janiak, C.; Vieth, J. K. New J. Chem. 2010, 34, 2366. (j) Qiu, S.; Zhu, G. Coord. Chem. Rev. 2009, 253, 2891. (k) Henninger, S. K.; Jeremias, F.; Kummer, H.; Janiak, C. Eur. J. Inorg. Chem. 2012, 16, 2625.

(2) (a) O’Keeffe, M.; Eddaoudi, M.; Li, H.; Reineke, T. M.; Yaghi, O. M. J. Solid State Chem. 2000, 152, 3. (b) Yaghi, O. M.; O'Keeffe, M.; Ockwig, N. W.; Chae, H. K.; Eddaoudi, M.; Kim, J. Nature 2003, 423, 705. (c) Ohrstrom, L.; Larsson, K. Molecular Based Materials: The Structural Network Approach; Elsevier: Amsterdam, 2005.

(3) Férey, G. Chem. Soc. Rev. 2008, 37, 191.

(4) O’Keeffe, M.; Yaghi, O. M. Chem. Rev. 2012, 112, 675 and references therein.

(5) (a) Braun, M. E.; Steffek, C. D.; Kim, J.; Rasmussen, P. G.; Yaghi, O. M. Chem. Commun. 2001, 2532. (b) Akiyama, G.; Matsuda, R.; Sato, H.; Takata, M.; Kitagawa, S. Adv. Mater. 2011, 23, 3294. (c) Horike, S.; Bureekaew, S.; Kitagawa, S. Chem. Commun. 2008, 471. (d) Zhao, Y.; Wu, H.; Emge, T. J.; Gong, Q.; Nijem, N.; Chabal, Y. J.; Kong, L.; Langreth, D. C.; Liu, H.; Zeng, H.; Li, J. Chem.-Eur. J. 2011, 17, 5101. (e) Biswas, S.; Ahnfeldt, T.; Stock, N. Inorg. Chem. 2011, 50, 9518. (f) Horcajada, P.; Salles, F.; Wuttke, S.; Devic, T.; Heurtaux, D.; Maurin, G.; Vimont, A.; Daturi, M.; David, O.; Magnier, E.; Stock, N.; Filinchuk, Y.; Popov, D.; Riekel, C.; Férey, G.; Serre, C. J. Am. Chem. Soc. 2011, 133, 17839. (g) Kandiah, M.; Nilsen, M. H.; Usseglio, S.; Jakobsen, S.; Olsbye, J.; Tilset, M.; Larabi, C.; Quadrelli, E. A.; Bonino,
F.; Lillerud, K. P. Chem. Mater. 2010, 22, 6632. (h) Lescouet, T.; Kockrick, E.; Bergeret, G.; Pera-Titus, M.; Farrusseng, D. Dalton Trans. 2011, 40, 11359. (i) Garibay, S. J.; Cohen, S. M. Chem. Commun. 2010, 46, 7700 .

(6) Rosi, N. L.; Eckert, J.; Eddaoudi, M.; Vodak, D. T.; Kim, J.; O’Keeffe, M.; Yaghi, O. M. Science 2003, 300, 1127.

(7) Deng, H.; Doonan, C. J.; Furukawa, H.; Ferreira, R. B.; Towne, J.; Knobler, C. B.; Wang, B.; Yaghi, O. M. Science 2010, 327, 846.

(8) Zhang, J.-P.; Zhang, Y.-B.; Lin, J.-B.; Chen, X.-M. Chem. Rev. 2012, 112, 1001 and references therein.

(9) (a) Galli, S.; Masciocchi, N.; Colombo, V.; Maspero, A.; Palmisano, G.; Lopez-Garzon, F. J.; Domingo-Garcia, M.; FernandezMorales, I.; Barea, E.; Navarro, J. A. R. Chem. Mater. 2010, 22, 1664. (b) Masciocchi, N.; Galli, S.; Colombo, V.; Maspero, A.; Palmisano, G.; Seyyedi, B.; Lamberti, C.; Bordiga, S. J. Am. Chem. Soc. 2010, 132, 7902. (c) Quartapelle-Procopio, E.; Linares, F.; Montoro, C.; Colombo, V.; Maspero, A.; Barea, E.; Navarro, J. A. R. Angew. Chem., Int. Ed. 2010, 49, 7308. (d) Colombo, V.; Galli, S.; Choi, H. J.; Han, G. D.; Maspero, A.; Palmisano, G.; Masciocchi, N.; Long, J. R. Chem. Sci. 2011, 2, 1311.

(10) Cohen, S. M. Chem. Rev. 2012, 112, 970 and references therein. (11) (a) Lozan, V.; Solntsev, P. Y.; Leibeling, G.; Domasevitch, K. V.; Kersting, B. Eur. J. Inorg. Chem. 2007, 20, 3217. (b) Maspero, A.; Galli, S.; Masciocchi, N.; Palmisano, G. Chem. Lett. 2008, 37, 956.

(12) Version 3.0; Bruker AXS: Karlsruhe, Germany, 2005.

(13) Diaz, E.; Ordoñez, S.; Vega, A. J. Colloid Interface Sci. 2007, 305, 7.

(14) Gross, R. S.; Guo, Z.; Dyck, B.; Coon, T.; Huang, C. Q.; Lowe, R. F.; Marinkovic, D.; Moorjani, M.; Nelson, J.; Zamani-Kord, S.; Grigoriadis, D. E.; Hoare, S. R. J.; Crowe, P. D.; Bu, J. H.; Haddach, M.; McCarthy, J.; Saunders, J.; Sullivan, R.; Chen, T.-K.; Williams, J. P. J. Med. Chem. 2005, 48, 5780.

(15) Jagtap, P. G.; Baloglu, E.; Southan, G. J.; Mabley, J. G.; Li, H.; Zhou, J.; van Duzer, J.; Salzman, A. L.; Szabo, C. J. Med. Chem. 2005, 48,5100 .

(16) See, for example: (a) Li, N.-H.; Frechet, J. M. J. J. Chem. Soc., Chem. Commun. 1985, 16, 1100. (b) Kumbhar, P. S.; Sanchez-Valente, J.; Figueras, F. Tetrahedron Lett. 1998, 39, 2573.

(17) See, for example: Raiford, C. J. Am. Chem. Soc. 1925, 47, 1456.

(18) At the same time, Long's group published another synthetic procedure for the same material where they were reacting $\mathrm{Zn}\left(\mathrm{CF}_{3} \mathrm{SO}_{3}\right)_{2}$ and the ligand in $\mathrm{N}, \mathrm{N}$-diethylformamide in a boron silicate tube for 5 days at $150{ }^{\circ} \mathrm{C}$. See: Choi, H. J.; Dincă, M.; Dailly, A.; Long, J. R. Energy Environ. Sci. 2010, 3, 117.

(19) Lu, Y.; Tonigold, M.; Bredenkötter, B.; Volkmer, D.; Hitzbleck, J.; Langstein, G. Z. Anorg. Allg. Chem. 2008, 634, 2411.

(20) Hansch, C.; Leo, A.; Taft, R. W. Chem. Rev. 1991, 91, 165.

(21) Actually, in our case, the sulfonate group is not protonated but bound to the Lewis acidic $\mathrm{Ni}(\mathrm{II})$ center. We assume that the $\sigma$ Hammett values of these two moieties are similar.

(22) It is worth noting that in the case of nitro-functionalized derivative an exothermic event is observed upon decomposition reasonably due to the oxidizing nature of the $\mathrm{NO}_{2}$ residue.

(23) (a) Choi, H. J.; Dincă, M.; Long, J. R. J. Am. Chem. Soc. 2008, 130, 7848. (b) Salles, F.; Maurin, G.; Serre, C.; Llewellyn, P. L.; Knofel, C.; Choi, H. J.; Filinchuk, Y.; Oliviero, L.; Vimont, A.; Long, J. R.; Ferey, G. J. Am. Chem. Soc. 2010, 132, 13782.

(24) Aguado, S.; Bergeret, G.; Pera Titus, M.; Moizan, V.; NietoDraghi, C.; Batsb, N.; Farrusseng, D. New J. Chem. 2011, 35, 546.

(25) Barea, E.; Turra, F.; Navarro, J. A. R. Gas Separation and Purification by MOFs (in Metal-Organic Frameworks: Applications from Catalysis to Gas Storage); Farruseng, D., Ed.; Wiley-VCH: New York, 2011.

(26) Li, J.-R.; Ma, Y.; McCarthy, M. C.; Sculley, J.; Yu, J.; Jeong, H.K.; Balbuena, P. B.; Zhou, H.-C. Coord. Chem. Rev. 2011, 255, 1791.

(27) (a) D’Alessandro, D. M.; Smit, B.; Long, J. R. Angew. Chem., Int. Ed. 2010, 49, 6058. (b) Sumida, K.; Rogow, D. L.; Mason, J. A.; McDonald, T. M.; Bloch, E. D.; Herm, Z. R.; Bae, T.-H.; Long, J. R. Chem. Rev. 2012, 112, 724. 
(28) Arstad, B.; Fjellvåg, H.; Kongshaug, K. O.; Swang, O.; Blom, R. Adsorption 2008, 14, 755.

(29) Guiochon, G.; Felinger, A.; Katti, A. M.; Shirazi, D. G. Fundamentals of Preparative and Nonlinear Chromatography; Elsevier: Amsterdam, 2006

(30) Montoro, C.; García, E.; Calero, S.; Pérez-Fernández, M. A.; López, A. L.; Barea, E.; Navarro, J. A. R. J. Mater. Chem. 2012, 22, 10155 